\title{
EL PATRIMONIO DE LOS REGULARES MADRILEÑOS EN LOS SIGLOS XVII Y XVIII
}

\author{
POR \\ Ceferino Caro López
}

Madrid

\section{RESUMEN}

El trabajo estudia la base material que proporcionaba el sustento económico a los regulares. Su patrimonio se componía de deuda pública, censos y bienes inmuebles en la ciudad y campo. La dinámica de dos siglos permite observar que la formación y gestión del patrimonio seguía criterios de racionalidad financiera. Las principales conclusiones del estudio son que el patrimonio de los religiosos se formo activamente y no pasivamente por acumulacion de donaciones y limosnas, y que el grado de crecimiento de los bienes amortizados disminuye entre los siglos XVII y XVIII.

\section{Abstract}

This paper studies the material grounds which provided the monastic orders with economical income. The patrimony of the church included juros, censos, and landed properties both in the city and in the country. A two-century trend shows that the patrimony was shaped and managed according to rational financial criteria. The main conclusions drawn from this study are that the patrimony of the Church was collected in an active rather than passive way of accumulating donations and legacies, and also that the growth of the ecclesiastical riches slowed its pace from the 17 th to the 18 th century. 
I PREMISAS.

"Y ast, mejor que en los erarios están en los templos depositadas las riquezas, no solamente por la necesidad extrema, sino también para que, floreciendo con ellas la religión, florezca el imperio".

(Saavedra Fajardo, Empresas Políticas)

La abundancia de estudios que en los últimos años han aparecido sobre la economía monástica en el Seis-Setecientos, por una parte hace absolutamente injustificada la pretensión de mantener al día y completa la bibliografía sobre el tema, y por otra ya no permite lamentar la falta de trabajos sobre la gestión y administración de las riquezas de monasterios y conventos en la Epoca Moderna. Esta investigación arranca de la premisa de que el funcionamiento de los institutos religiosos es de naturaleza básicamente económica. No se pretende analizar ni valorar su peso en la cultura y la sociedad en las prestaciones morales que brindaban a los contemporáneos ni reducirlas a las no menos evidentes consecuencias económicas que su presencia tenía; tampoco pretende juzgar si uno de estos aspectos estaba o no justificado por el otro; menos todavía desea discutir si era legítima, justa o necesaria la propiedad y gestión de bienes materiales por parte de los religiosos regulares. Más sencillamente, se mueve del hecho irrefutable de que la dimensión económica era la conditio sine qua non para la existencia de los conventos, y como tal se intenta estudiarla en algunos de sus aspectos; por ello convendrá fijar algunos de los conceptos sobre los que se ha trabajado.

El interés principal del estudio se ha centrado en los bienes de los conventos y monasterios madrileños ${ }^{1}$. Al concretar este epígrafe, hemos tenido pre-

1 Fuentes manuscritas*

Agustinas calzadas Sta. Maria Magdalena: 1601=lib. 6891; 1621=lib. 6892

Agustinos calzados D* MP de Aragón: 1678-lib. 8041; 1722-1732=8042; 1716-1773-mss.3874.

Agtustinos descalzos recoletos S. Agustín: 1673-lib. 6772; 1713mlib. 6819.

Agustinos recoletos calzados S. Felipe el Real: 1755-1798-lib. 6824.

Agustinos recolelos descalzos Definitorio: 1729-1760-mss.3873.

Benedictinos S. Martín: archivo del monasterio, 1700-1828-libs. 8544 a 8569 (26 vols.).

Bemardas Piedad "Vallecas": 1606-1628-lib. 7315; 1624-lib. 7214; 1618-1667-lib. 7217;

1639-lib. 7205; 1699-Jib. 7216; 1764-lib. 7208.

Bemardas Purisima Concepción de Pinto: 1715=lib. 1634; 1786-jib. 7176.

Carmelitas calzados $N^{*} S^{*}$ del Carmen: 1640-1649-1ib. 7048; 1646= lib. 7031; 1741mlib. 6979; mss. 3820 .

Clérigos menores Portaceli S. Felipe Neri: 1702-lib. 7563; 1773- 7575 .

Clérigos menores seculares $S$. Salvador: 1680-8075.

La época de Felipe Il y los Ausırias

Hispania Sacra 50 (1998) 
sente a Moreta Velayos, para quien todos los ingresos percibidos regularmente debían entenderse como "rentas"2. Aquí se han considerado los bienes religio-

Dominicas Sta. Catalina de Sena: 1603-lib. 7284; 1616-1630-lib. 7286; 1706-lib. 8073; 1707-lib. 7262; 1761-lib. 7271; 1768-lib. 7274; 1774-lib. 7263; 1777-lib. 7280; 1788=lib. 7265; y libs. 7270; 7286ter; 7281; 7272; 7273; 7277; 7282 .

Franciscanas menores Purisima Concepción: 1761=lib. 7402; para el catastro, libs. 7417, $7418,7419,7420,7421,7422,7423,7424$.

Franciscanas menores Salutación "Constantinopla": 1604-lib. 7476; 1624-1690-lib. 7448; 1706-lib. 7750; 1723-lib. 7449.

Franciscanas Sta. Clara "Visitación": 1607-1630=lib. 7974; 1668-1671-lib. 7393; 1672 -

1676-lib. 7784; 1771-1785-lib. 7390.

Jerónimas Concepción: 1695-lib. 7512.

Merced: 1674-lib. 7948; 1771 =lib. 7741; también AHN, Consejos, leg.585.

Mostenses S. Basiio: 1644-1692= lib. 6951; 1676-lib. 8054; $1677=$ mss.3877; 1693-

$1700=$ lib. 6939; 1767=lib. 1767; Archivo de S. Basilio 1696-1828=libs.6912 a 6925 (14 vols.).

Mostenses S. Joaquín: 1686-1687=lib. 7903.

Mostenses S. Norberto: 1672-1735=lib. 7907; 1757=7909.

Trinitarios SS" Trinidad: 1605-1616-lib. 7950.

"Las signaturas se refieren al documento que abarca la fecha o el periodo indicado: lib. =AHN, Clero, libro; mss.=BNM, Manuscritos.

Desde ahora, y por razones de comodidad y estilo, los términos "convento", "monasterio" y "cenobio", aunque no exactamente sinónimos desde el punto de vista técnico, se usarán indistintanente.

2 MORETA Velayos, Rentas monísticas en Castilla: problemas de métado, Salamanca 1974, p. 81. También M. RuU, Esquema metodògic per a l'estudi d'un monessir: I Collogui d'història del monaquisme català, I, 1967.

Para la economía y la admisnistración de los conventos, véanse Agricultura, comercio colonial y crecimiento económico en la España contemporánea, Barcelona 1974; Agricultura e llustración, ed. Argeni d'Abadal, Madrid 1988; J.A. ALVAREZ VAZQUEZ, Diezmos y agricultura en Zamora 15001840, Salamanca 1977; J. P. AMALRIC, En el siglo XVIII: ¿Una agricultura agarrotada?: Origenes del atraso económico espafol, Barcelona 1985; G. ANES, Las crisis agrarias en la España moderna. Madrid 1970; ID. El Antiguo Régimen: Los Borbones, Madrid 1975; M. ARTOLA, Propiedad, asigna. ción de recursos y distribución de rentas en la agricultura del Antiguo Régimen: Estudios de Historia Social, 1, 1977; ID. El latifundio. Propiedad y explotación, ss. XVIII-XX, Madrid 1978; A. ATIENZA LOPEZ, Propiedad, explotación y rentas: el clero regular zaragozano en el siglo XVII, Zaragoza 1988; B. BENNASSAR, ed. Orígenes del atraso económico español, Barcelona 1985; A. M. BERNAL, Disolución del régimen señorial en Andalucia Occidental; Historia agraria de la España contemporánea, I, Barcelona 1985; CAMINAL, CANALES, SOLA, TORRAS, Movimiento del ingreso sehorial en Catalufia (1770-1833). Los arriendos de la Casa de Medinaceli: Historia agraria de la España contemporanea, I, Barcelona 1985; E. CANALES GILI, Los diezmos en su etapa final: La economía espatiola a finales del siglo XVIII y principios del XIX, Madrid 1982; ID. Diezmos y revolución burguesa en España: Historia agraria de la Espahia contemporánea, I, Barcelona 1985; C. CARo LóPEZ, Casas y alquileres en el antiguo Madrid: Anales del Instituto de Estudios Madrileños, XX, 1983; ID. Las cuentas del monasterio de San Martín a finales del siglo XVIII: Anales del Instituto de Estudios Madrileños, XXX, 1991; J. CARRERA PUJAL, Historia de la economía española, IV, Barcelona 1945; J . COSANO MOYANO, Propiedad agraria, rentas y monopolios señoriales en Fernán-Núñez a mediados del siglo XVIII: III Congreso de Profesores Investigadores, Huelva 1986; A. DOMiNGUEZ ORTIZ, Las rentas de los prelados de Castilla en el siglo XVI: Anuario de Historia Económica y Social, III, 
sos como fuentes de "renta", ora bajo forma de ingresos por alquileres o censos, ora como producto de los predios explotados directamente. También se entiende por renta los intereses de censos y juros estipulados por los religiosos

1970; ID. La villa y el monasterio de Sahaguin en el siglo XVHI: Homenaje al Profesor Carriazo, II, Sevilla 1972; ID. Las rentas episcopales de la Corona de Aragón en el siglo XVIII: Agricultura, comercio colonial y desarrollo económico en la España contemporánea, Barcelona 1974; ID. Campomanes y los «monjes granjeros»: Cuadernos de Investigación Histórica, I, 1977; ID. Aspectos sociales de la vida eclesiástica enlos siglos XVII y XVIII: Historia de la Iglesia en España, IV, Madrid 1979; ID. Un alegato de los párrocos de la diócesis toledana contra el desigual reparto de los diezmos: Hispania Sacra, 33, 1981; La economia española a finales del siglo XVIII y comienzos del XIX, Madrid 1982; EQUIPO MADRID, Carlos III, Madrid y la llustracion, Madrid 1988; R. FERNANDEZ CARRION, Estudio de historia agraria andaluza. Rentabilidad de una explotación agraria en el siglo XVIF: III Congreso de Profesores Investigadores, Huelva 1986; J. FERREIRO PORTo, Aportación al estudio de la renta en el Antiguo Régimen: La Historia social de Galicia, Santiago 1980; J. FONTANA LAZARO, La crisis agraria de comienzos del siglo XIX y sus repercusiones en España: Historia agraria de la España contemporánea, Barcelona 1985; F. FRANCH BENAVENT, El régimen señorial del convento de Aguas Vivas durante el siglo XVIII: Estudis, 8, 1979-1980; M.D. GALBIS BLANCO, Un monasterio valenciano: Primer Congreso de Historia del Pats Valenciano, III, Valencia 1973; GRUPO 75, La economía del Antiguo Régimen. La urenta nacional» de la Corona de Castilla, Madrid 1977; C. HERMANN, Les revenus des évêques espagnols au dix-huitième siècle (1650-1830): Melanges de la Casa de Velázquez, X, 1974; ID. Patronage royal et dimes: l'enquête décimale de Grenade, de 1757: Melanges de la Casa de Velázquez, XI, 1975; Historia agraria de la España contemporánea, ed. de GARCIA SANZ- GARRABOU, 3 vols. Barcelona 1985-86; Historia de la Iglesia en Espaffa, Madrid 1979; P. INGUANZO Y RivERO, El dominio sagrado de la Iglesia en sus bienes remporales, Salamanca 1820-23; E. LLOPIS AGELLAN, La economía monástica al final del Antiguo Régimen en Extremadura, Madrid 1980;1D. Algunas consideraciones acerca de la producción agraria castellana en los venticinco últimos años del Antiguo Régimen: Historia agraria de la España confemporánea, Barcelona 1985; A. L. LOPEZ MARTINEZ, La economía de las órdenes religiosas en el Antiguo Régimen, Sevilla 1992; Madrid, Carlos $1 /$ y y la llustración, Madrid 1988; E. MARTIN, Valor de la Iglesia de Asturias en el siglo XVIII: Boletín del Instituto de Estudios Asturianos, XXXI, 90-91, 1977; J. MiLlaN Y GARCIA-VARELA, Rentistas y campesinos, Alicante 1984; A. MORA CAÑADA, Monjes y campesinos, Alicante 1986; S. MORETA Velayos, Rentas monásticas en Castilla: problemas de método, Salamanca 1974; M.D. MUÑ̃z DUEÑAS, El diezmo en el obispado de Córdoba, Córdoba 1988; M. PESET, Dos ensayos sobre la historia de la propiedad de la tierra, Madrid 1988; J.M. PIÑERO CARRION, La sustentación del clero, Sevilla 1963; J.M. RECASENS I COMES, Les rendes del monestir de Poblet a l'arquebisbat de Tarragona a final del segle XVII: I Colloqui d'història del monaquisme català, I, 1967. M. RIU, Aspectes socioeconòmics de la historia mondstica: Scriptorium Populeti 7, 1970; A. RODRIGUEZ FRAIZ, Tierra de Montes, Pontevedra 1973; J. ROMERO GONZALEZ, Propiedad agraria y sociedad rural en la España mediterránea, Madrid 1983; M. Ros, Historia de las rentas de las iglesias de España desde su fundación hasta el siglo presente, Madrid 1741; N. SANCHEZ ALBORNOZ, Madrid ante la Castilla agraria del siglo XIX, Madrid 1983;G. SANCHEZ MECO, Análisis económico de una comunidad monástica: Revista Internacional de Sociología, 36, 1978; ID. El Escorial y la Orden Jerónima, Madrid 1985; R. SANSANO, El privilegio de diezmar y ofrendar. Terrassa, 1988; J. SEMPERE Y GUARINOS, Historia de las rentas eclesiásticas de España, Madrid 1783; J. DE VINUESA, Diezmos de legos en la Iglesia de España, Madrid 1791; C. VIZUETE MENDOZA, La disolución del patrimonio del monasterio de Guadalupe: Hispania Sacra, 69, 1982.

La época de Felipe II y los Austrias

Hispania Sacra 50 (1998) 
en beneficio de sus casas, y los alquileres de las fincas urbanas. Sin embargo también son ingresos las limosnas recibidas en los conventos, las fundaciones de capellanías, las misas pagadas a los cenobios. De hecho estos tipos de ingresos tenían peso social muy distinto, y como tales deberían ser valorados, si no aquí, sí en otras investigaciones. Lo que se define y acepta aquí por "patrimonio" representa el campo de acción de una gestión económica realizable en base a criterios objetivos y concretos: introducción de mejoras en la explotación agraria, política de precios de los productos de las tierras, y su comercialización, maniobras especulativas en las inversiones, diversificación de las inversiones, etc.

Probablemente los resultados no sean definitivos por las lagunas en los datos, pero son seguramente significativos. Uno de los factores centrales, en efecto, es el aspecto dinámico que permite subrayar, primero, que los ingresos y bienes de las instituciones religiosas de los regulares han suftido grandes variaciones en el período estudiado; segundo, que dichas variaciones fueron cuantitativas y cualitativas; y tercero, que el movimiento de cambio no se debió ni a la inercia del tiempo ni al capricho de la voluntad de los donadores, sino que se emprendió con el evidente fin de racionalizar el patrimonio y aumentar al máximo los beneficios.

La periodización temporal también permite fijar los momentos clave de tal proceso en Madrid, proceso que puede o no coincidir con la dinámica general del país.

Siempre que ha sido posible se ha intentado también recabar los datos acerca de las relaciones económicas entre regulares y sociedad civil; en el ćaso de las empresas agrarias, estudiando la información disponible sobre alquileres y pactos en las fuentes; por lo que se refiere a censos, juros y casas en la ciudad la relación es más clara y en el caso de las dos primeras fuentes de ingresos el margen de maniobra era muy limitado a causa de las reiteradas intervenciones de la Corona en asuntos de intereses de deuda pública y préstamos, hasta convertirse en el fondo en un dejar o tomar.Ya se verá cómo, cuando la rentabilidad de este tipo de inversiones ya no era interesante, los religiosos dejaron tales prácticas para tomar interés en otros campos más prometedores.

Siempre que ha sido posible se ha evitado toda referencia a datos monográficos, excepto en aquellos casos en que las series documentales eran realmente fuera de lo corriente por calidad y cantidad, como por ejemplo para el monasterio de San Martín o el convento de Santa Catalina de Sena; en general los datos han sido analizados y homogeneizados para poder tratarlos bajo una visión global de la Iglesia regular en la Corte. Para este fin se ha adoptado el 
modelo de Sánchez Meco de clasificación de los patrimonios "en grupos perfectamente definibles e interrelacionados"3.

El estuđio más exhaustivo sobre los bienes de los regulares es probablemente el debido a López Martínez pero no se ha seguido su sistema dadas las distintas fuentes consultadas, pues un trabajo realizado principalmente sobre el Catastro de Ensenada siempre tendrá un carácter de síntesis, de recapitulación, esto es cerrado, mientras que el estudio realizado sobre los documentos internos de los conventos será más inmediato, abierto al análisis temporal, aunque también más fragmentario.

\section{Fuentes}

La cuestión de las fuentes es de hecho la decisiva. Se ha evitado la centralidad del Catastro bien por su carácter oficial -luego abierto a la ocultación y al fraude- bien por su carácter estático —anclado como está a mediados del Setecientos. En cambio, los instrumentos contables de los religiosos, aunque difíciles de manejar por algunos aspectos, son muy homogéneos entre sí, y siendo instrumentos de administración real de los conventos, no contienen falsificaciones ni ocultaciones. Barrio Gozalo y García Martín ya tuvieron ocasión de lamentar la dificultad de uso de estos papeles al indicar los criterios $\multimap$ falta de ellos - de contabilidad que aplicaban los religiosos. Generalmente los ingresos se indicaban en el orden en que eran recibidos, por lo que es preciso agrupar las entradas primero en sus oportunos conceptos para poder después analizarlas. En los mismos libros se mezclan productos de las tierras, de las cosechas, frutos de censos y juros, limosnas, alquileres de casas y pagos por misas. Otros registros, los libros de Recibo y Gasto a veces se especializaban en granos, o rentas, o administración de fincas. Ś́lo los documentos usualmente llamados Libros del Archivo ofrecen noticias de conjunto sobre el objeto de la recaudación, sus causas y sus condiciones, pero todos los registros especifican para cada percepción su cuantía, la fecha de origen del tributo, el nombre del pagador, y en los casos de censos el nombre del deudor junto con la fecha de imposición. De ahí es por lo tanto posible recomponer el conjunto de las rentas y su devenir.

El desordenado seguimiento contable es un factor poderoso para retocar el mito de la administración rigurosa de los bienes de los religiosos, pero no el único, pues se pone de manifiesto también la incuria material para cuidar de sus mismos intereses. Así, el libro de la administración de bienes de San Basilio estaba

3 SÁNCHEZ MECo, Análisis económico de una comunidad monástica; Revista Internacional de Sociologia, 36, 1978, p. 23.

La época de Felipe Il y los Austrias

Hispania Sacra 50 (1998) 
reducido a 14 foxas de 240 útiles que consta tenía en el año de 1761 en que se dio principio a las anotaciones de Cuenta y razón de sus productos 4 .

Faltando físicamente el registro, el control de la gestión sólo podía ser muy defectuoso; pero las usurpaciones y dejadeces en otras muchas ocasiones habían reducido las rentas y los derechos de los monasterios, como en el caso de un convento tan organizado como podía ser el de Santa Clara:

en los memoriales antiguos decía que Dionisio Gil vecino de Vallecas tenía arrendadas unas tierras perteneciente a este Convento en los términos de Madrid Vallecas y Villaverde pero no constaba ni en Becerro, ni en relación de hacienda, ni memoriales qué tierras eran, qué fanegas ni qué linderos [...] hora están vacantes porque no ha parecido conveniente arrendarlas hasta saver a punto fijo las tierras que son 5 .

Y los Clérigos Menores de San Felipe Neri decían de algunos bienes que

pertenecen a esta Casa unos creditos antiguos (se cree) sin otra carga que encomendarles [los donadores] a Dios ${ }^{6}$.

El aspecto más interesante, en cualquier caso, de este proceso de pérdida continua de los títulos patrimoniales es que, a pesar de todo, los ingresos globales no disminuían de manera apreciable, como pueden dar fe los registros de las Franciscanas Menores de la Concepción en el curso del siglo XVIII, donde se puede observar perfectamente el hecho? ${ }^{7}$. No hay prácticamente libro, por bien llevado que estuviera, que no tuviera tarde o temprano que declarar que algún derecho había caído en olvido o se habían extraviado sus escrituras originales. Así que nunca deberá perderse de vista que, por mucho que los documentos son sustancialmente fiables, no se puede pretender de ellos exactitud al cien por cien. Por otra parte los mismos administradores estaban bien enterados de todas estas limitaciones. Como único botón de muestra, las curiosas "advertencias al Cobrador" que, aunque escritas para el convento de Mercedarios de Segorbe, son universales 8 , y donde, entre otras cosas, se dice al cobrador a propósito de los títulos y derechos:

4 AHN, 6922, f. 350. En 1747 se promulgó una Real Cédula para intentar poner orden en la administración de las rentas de la Capilla de San Isidro, 3/IX/1747.

5 AHN, 7271 f. 48.

6 AHN, 7275 f. 45 .

7 AHN, 7419.

8 AHN, 2738, f. 2, 1775 . 


\begin{abstract}
Y nunca omita esta diligencia para anotarlo en el libro mayor de Renta, donde corresponda; porque este cuidado asegura los Censos, y por su omision se han perdido muchos.
\end{abstract}

Las dificultades en el manejo de las fuentes dependen también de la manera en que se llevaban los registros, entre los que hay algunos casos realmente exasperantes, como las cuentas de las abadesas de las franciscanas menores de la Salutación o Constantinopla entre 1627 y 1690.Estaban bajo la tutela de un adminstrador varón, en Madrid el Contador de las Cuentas de la Hacienda de los Conventos de esta Santa Provincia de Castilla, quien verificaba en los libros contables los datos

de los juros que hestan a su cargo para cumplimiento delas memorias de missas, y otros gastos del oficio y asi mesmo de los expolios que hobieren havido y limosnas que hubieren entrado, y demas mrs. que hubiere percibido en dicho tiempo?.

Pero por otra parte, como se puede apreciar por otro apunte del mismo libro, parece ser que a veces el déficit, incluso en ocasiones notable, en las finanzas de los conventos, era parcialmente deseado o por o menos no era sentido como algo negativo, puesto que algunas abadesas, en el momento de presentar las cuentas de su mandato, declaraban que

hace gracia de dicho alcance al Convento, y que quisiera haber tenido más possivilidad para servir y regalar a las Señoras Religiosas y aber cumplido en todo como es su boluntad [en 1690].

Es decir, que la abadesa saliente perdonaba al convento las deudas que éste tenía para con ella (el alcance a su favor), deudas que curiosamente se habían originado durante su gestión. Era una práctica corriente en la administración de estas madres pues ya otro Contador de las Cuentas, Fray Bernardo de San Antonio, vicario del monasterio de Santa Clara de Guadalajara, en 1675 les recordaba:

adviertese de aquí adelante las Madres Abbadessas no an de gastar en extraordinarios, ni en los demás gastos que han Corrido, y corren por su Cuenta más quantidad de la que montaren las limosnas que adquirieron con su Cuydado ansí sueltas como para officios, entierros, y Missas, de que han de dar quenta, sin que pueda entrar en su poder

AHN, 7448, f. 141. Las dos referencias siguientes remiten a los ff. 150v. y 49.

La Época de Felipe II y los Austrias

Hispartia Sacra 50 (1998) 
mrs. Algunos de Axuares, alimentos, Herencias de Religiosas que se dan libremente al Convento para officios missas, y entierros, particulares (10/III/1675).

¿Será tal vez posible ver en estas declaraciones un deseo de ganarse la popularidad entre las monjas? ¿O es que en el momento de hacer las cuentas -económicas - se hacía profesión de desapego a los intereses terrenales en vistas a otras cuentas por rendir, las definitivas?

En este estudio el interés se ha centrado en las fuentes de los ingresos de los conventos descuidando los gastos porque los datos por este concepto son mucho más escasos, y no se ha querido hacer un balance general de las actividades económicas desde el punto de vista contable, sino estudiar los orígenes de los ingresos y sus cuantías.

Las fuentes principales de esta investigación han sido por tanto:

a) libros de cuentas de los conventos, con los apuntamientos generales de los ingresos especificados en cada caso: tierras, casas, censos, etc.

b) libros de los apeos, almocraces, inventarios de bienes inmuebles de los regulares, para reconstruir los patrimonios;

c) las colecciones de instrumentos de censos y juros de propiedad de los conventos;

d) en los casos en que están disponibles, los registros de los archivos de conventos y monasterios. Se trata de colecciones ordenadas cronológicamente de todos los instrumentos y escriturasde cada casa, y representan una fuente riquísima de noticias sobre el desarrollo patrimonial de un cenobio. Los fondos consultados son en su mayor parte los custodiados en el Archivo Histórico Nacional, sección Libros de Clero, de la que se han visto, analizado y elaborado todos los tipos de fuentes arriba especificados y relativos a la ciudad de Madrid.

El punto de vista exclusivo puesto en los regulares se explica por el hecho de que la base documental es abundante y relativamente accesible y también porque en el curso del siglo XVIII y parte del siguiente representaron a los ojos de ciertos ambientes políticos y sociales el prototipo de la riqueza improductiva y del parasitismo social, contra los que se tomaron las primeras medidas de reforma económica y de desamortización.

Bien lo sabía Campomanes, quien en su Segunda Alegación escribía de la Corte, tras haber pasado revista a las ciudades castellanas:

A la vista de un Madrid, cuya sustancia y raices se reducen únicamente á malas tierras, a casas todas arrendables y a los precisos efectos de villa [...] Donde quien quiera convencerse y asombrarse del exceso de casas, y de los efectos de villa en manos muertas, y de la rapidez con que en herencias, fundaciones, y compras va creciendo su 
adquisición, vaya á la contaduría de las Casas de aposento, y á la de Sisas de la villa, donde están á la mano las razones [...] y quien quisiere salir de Madrid las verá [las manos muertas] cómo se han estendido y se estienden más cada día por los términos de Torejon de Ardoz, de Rejas, de Mejorada, de Loeches, de Arganda, de Morata, de Valdemoro, de Pinto, de Esquivias y de otros pueblos, y que han precisado á la piedad y justicia del Rey, á consulta de este Supremo á espedir los decretos que se están ejecutando ${ }^{10}$.

Además la continuidad de las fuentes permite también seguir dinámicamente esta realidad a lo largo de un período temporal bastante indicativo.

La elección de Madrid era obligada por el número de establecimientos religiosos que tenía, por tratarse de la capital y por el carácter artificial del desarollo de la ciudad y de sus conventos. De hecho su gran mayoría fue fundada en la misma época, por lo que es posible observar el fenómeno de su crecimiento desde el principio. La periodización, por cuanto es arbitraria siempre, tiene buenas justificaciones en este caso; empezar desde principios del Seiscientos significa tomar prácticamente la fecha de fundación de casi todas las casas, y la Guerra de la Independencia es para ellas un momento de crisis del que saldrían muy alcanzadas, para resistir hasta Mendizábal con un esplendor ya reducido.

\section{LOS PATRIMONIOS}

Según la Noticia de todos los conventos que hay en Madrid, en qué año se fundaron y por qué Sujetos, de la Biblioteca Nacional'", en el siglo XVIII ha-

10 Segunda Alegación, en J. Alonso, Colección de alegaciones de Campomanes, III, Madrid 1842. p. 155.

Para la políitica de los Ilustrados, véanse J. M. CUENCA TORIBIo, La Iglesia española en la crisis del Antiguo Régimen (1789-1833): Homenaje al Dr. D. J. Reglá Campistol, Valencia 1975; IZQUIERDO, LÓPEZ, MARTÍN, MÉNDEZ, MORENO, DE PABLO, La reforma de regulares en el reinado de Carlos III. Una valoración a través del ejemplo madrileño: Carlos III, Madrid y la Ilustración, Madrid 1988.

11 BNM, mss. 10.923, $\mathrm{n}^{\circ} 40$. Sin embargo, otro documento de 1767, el Plan que contiene... BNM, mss. 6966- cifra los cenobios masculinos en 36 y los femeninos en 31. Más allá de la exactitud numérica, lo que interesa ahora es hacer notar que la multitud de institutos religiosos hacía perder las cuentas hasta a los mismos contemporáneos. Sobre los regulares cspañoles, P.L. DE AMOROS, Estadística de los conventos y religiosos de la Provincia Franciscana de España en el año de 1767: Archivo Iberoamericano, 64, 1956; N. BACKMUND, La orden premostratense en España: Hispania Sacra,35, 1983; M. BARRIo GOZALO, Estudio socio-económico de la Iglesia de Segovia en el siglo XVIII. Segovia 1982; ID. Los conventos de monjas en la Segovia de finales del Antiguo Régimen (1768-1836): Hispania Sacra, 45, 1993; ID. El clero regular en la España de mediados del siglo XVIII a través de de la eEncuesta de 1767\%: Hispania Sacra, 47, 1995; J. FERNANDEZ MARTIN, Apuntes y documentos para la historia del Carmen Calzado en Madrid, Madrid 1950; L. FERNÁNDEZ

La época de Felipe II y los Austrias

Hispania Sacra 50 (1998) 
bía en la corte 41 cenobios masculinos y 30 femeninos, de los que veinte preexistían a la capitalidad de 1561 y algunos de los cuales se remontaban a la Edad Media. La fiebre de fundaciones nuevas se verificó indudablemente en los años inmediatamente sucesivos a la llegada de la Corte a la ciudad, porque en el período entre 1570 y 161014 conventos masculinos y 6 femeninos aparecieron en la Villa. Durante todo el Seiscientos el número de conventos de nueva fundación fue prácticamente igual -24 - a los que habían abierto sus puertas en los treinta años anteriores; y esta vez el número de casas es igual para hombres y mujeres. Una vez agotado el empuje fundacional, en el Setecientos son escasos los nuevos institutos y en cierto grado es significativo que aparezcan no casas de vida claustral sino congregaciones noviciales y hermandades abiertas a la vida de la sociedad.

La riqueza patrimonial de todas estas instituciones era enorme y puede ser catalogada bajo tres distintas especies: títulos de deuda pública - juros y efectos de villas--, préstamos hipotecarios —censos- y bienes raíces, a su vez urbanos y rústicos.

\footnotetext{
MARTín, Estado espiritual y temporal de los monasterios bernardos de Galicia en vísperas de la Guerra de la Independencia, Hispania Sacra, 44, 1992; M. DE FORONDA y AGUILERA, La abadia de San Martín, Madrid 1911; G.A. FRANCO RUBlO, La Iglesia secular de Madrid en el siglo XVHI, Madrid 1986; ID. La organización eclesiástica del Madrid de la Ilustración, Anales del Instituto de Estudios Madrileños, XXII, 1986; P. GARCIA MARTIN, El monasterio de San Benito el Real de Sahagún en la época moderna, Satamanca 1985; A. LINAGE CONDE, EI monacato en España e Hispoanoamérica, Salarnanca 1977; F. MARTJ GlLABERT, La Iglesia en españa durante la Revolución Francesa, Pamplona 1971; DEL OLMO, SANChEZ Esteban, MONTILA, El colegio de Doña María de Aragón: Anales del Instituto de Estudios Madrileños, 23, 1986; J. SAEZ MARIN, Datos sobre la Iglesia española contemporánea 1768-1868, Madrid 1975; A. VELASCOZAZO, Madrid monacal, Madrid 1943.

Sobre los aspectos históricos y sociales más cercanos al tema de esta investigación, son útiles $\mathrm{M}$. ARTOLA, La hacienda del Antiguo Régimen, Madrid 1982; ID. La Espana de Fernando VII: Historia de España, vol. XXXII, Madrid 1983; W. CALLAHAN, Iglesia, poder y sociedad en España, 1750 1874, Madrid 1989; COLlANTISS PEREZ-ARDA - MERINO NAVARRO, Alteraciones al sistema monetario de Castilla durante el reinado de Carlos I: Cuadernos de Investigación Historica, 1, 1977; A. DOMinguez ORTIZ, Politica y hacienda de Felipe IV, Madrid 1960; E. FERNÁNDEZ DE PINEDo, Coyuntura politica y economia: Centralismo, Ilustración y agonia del Antiguo Régimen: Historia de España, VII, Barcelona 1980; J. FONTANA LAZARo, La Hacienda en la historia de España, Madrid 1980; ID. (ed.) Crisis del Antiguo Régimen 1808-1833, Barcelona 1983; R. HERR, España y la revolución del siglo XVIII, Madrid 1988; ID. La Hacienda Real y los cambios rurales en la España de finales del Antiguo Régimen, Madrid 1991; La invasió napoleónica. Economia, cultura i societat, Barcelona 1981; H. KAMEN, La España de Carlos II, Barcelona 1981; A. MARTINEZ ALBIACH, Religiosidad hispana y sociedad borbónica, Burgos 1969; A. MATTLLA TASCON, La Unica Contribución y e Catastro de Ensenada, Madrid 1947; A. MESTRE SANCHIS, La Iglesia en la España de los siglos XVII y XVIII: Historia de la Iglesia en España, IV, Madrid 1979; Pragmática [...] sobre minoración de los réditos de los censos, 12/I/1705; M. SARMEENTO, Papel sobre el ocho por ciento..., BNM, mss. 1743.
} 
Juros.

La adquisición de deuda pública es un dato común en la práctica económica de muchas, por no decir la totalidad, de las casas y no sólo para colocar capitales en efectos de la Villa de Madrid sino en cualquier título ofrecido por el fisco y que tuviera visos de buena rentabilidad ${ }^{12}$. Así, el convento de San Martín poseía $322.494 \mathrm{mrs}$. de principal en el Setecientos, invertidos en cuatro títulos sobre las Alcabalas de Uceda, tres de Málaga, dos sobre Ocaña y Madrid, otros tantos sobre las Salinas de Atienza y los Servicios de Montazgo, y uno cada uno en el Cuarto y Medio por ciento de la Villa de Burgos, Millones de Cuenca, Servicio Ordinario de la Villa de Jaén, Salinas de Murcia y Estanco del Tabaco. Las dominicas de Santa Catalina de Sena tenían en 1630 un juro sobre las Acabalas de Madrid de $6.000 \mathrm{mrs}$. de renta anual y dos en las Alcabalas de Sevilla, uno en las de Guadalajara y otro en el Alholí de la Villa, pero en 1704 sus inversiones en deuda pública se habían multiplicado: 28 juros impuestos al 3\%. Globalmente, en un siglo el convento había comprado deuda por un valor de 443.900 reales, que en 1774 se habían convertido en 632.660 con algunas inversiones realmente considerables de por sí, como los 80.000 rs. situados en el Error de Medidas del Vino, o los 60.000 en la Cuarta Blanca del Carbón, o los 46.000 rs. de la Moderada de las Carnes, o el más conspicuo, 80.600 reales al 3\% anual en los Millones de Salamanca.

Posteriores medidas regularon por razones de tesorería los intereses a cobrar por juros y censos, pero hacia principios del Seiscientos dichos intereses variaban mucho, siendo en algunos casos elevadísimos. Según los datos del convento de agustinas calzadas de Sta. María Magdalena, en 1570 se estipuló un juro - sin especificar cuál-al 10,15\% anual, mientras que en 1602 la tasa de interés media era de $2,86 \%$. Estando así las cosas, lo lógico sería suponer que las inversiones respondieran a la búsqueda del más alto margen de ganancia, pero, según indica la contabilidad de las casas, como las inversiones sólo se realizaban cuando la disponibilidad de capitales las hacían posibles, no se podían beneficiar totalmente de las oportunidades coyunturales; en 1570 se invirtieron $19.000 \mathrm{mrs}$. al $10,15 \%$ mientras que cinco años después cuando el

12 Entre lo cuales había algunos, probablemente antiquísimos, pagados en especies. Parecen excepcionales en la Edad Moderna, y sólo se ha encontrado una mención en los libros de cuentas del convento de franciscanas menores observantes de Constantinopla, para el año de 1604:

"Juro de pan.Tiene este convento un juro en pargomino con su sello grande de plomo pendiente de cordones de seda de colores despachado en toda forma sobre las Tercias de Xetafe y Leganes de noventa y nueve fanegas y nueve celemines de trigo y otras tantas de cevada en cada un año pagadas por el día de Todos los santos. Por ser tan antiguo no se puede leer la data ni firma. Pero ay otro con los mismos requisitos y cantidad despachado en forma en la Villa de Ocaña a veynte y ocho de henero de mill y quatrocientos y noventa y nueve años", AHN, 7446, f.1.

La época de Felipe II y los Austrias

Hispania Sacra 50 (1998) 
convento pudo disponer de 1.100 .000 mrs. hubo de comprar deuda a interés muy inferior, del $5,45 \%$ solamente. Otro caso límite semejante se puede encontrar en los años 1601-1602, cuando se invirtieron dos cantidades muy parecidas, 550.000 y 561.000 maravedíes en dos juros, uno al $4,09 \%$ el otro al $2,86 \%$. En buena lógica el inversor debiera haber desechado las ofertas que daban intereses más bajos, pero estos ejemplos y el hecho de que muchos de estos títulos llegaban al convento bajo forma de donaciones de los feligreses hacen pensar que no hubo una política consciente orientada hacia la especulación de capitales en deuda y renta fijas. Se trataba antes sí de una acción refugio tendente a asegurar los capitales que la caja del convento arrojaba como excedentes, lo que no ocurría con regularidad, como más abajo se verá.

De la tabla 1 se concluye una doble periodización de esta actividad económica. Lamentablemente los datos se refieren a pocas comunidades, las únicas

TABLA 1. a) Capitales invertidos en juros por los conventos de Madrid, 16001800. Totales acumulados en reales.

\begin{tabular}{lrrrrc} 
& ante 1600 & 1650 & \multicolumn{1}{c}{1700} & 1750 & 1800 \\
\cline { 2 - 6 } Sta. Catalina & & & 473.900 & 632.660 & 632.660 \\
Sta. Clara & & 581.539 & 583.603 & 579.241 & 579.241 \\
Magdalena & 210.567 & 549.900 & & & \\
Recoletos & & & & 663.480 & \\
S. Felipe R. & & & & 2.059 .233 & \\
S. Basilio & 13.500 & 852.966 & 1.500 .066 & 1.500 .066 & \\
Vallecas & 50.087 & 311.298 & 687.633 & 687.633 & \\
Carmen & & 642.900 & & 1.461 .633 & 1.461 .633 \\
S. Felipe N. & & & 459.133 & 476.033 & 476.033 \\
S. Salvador & & & 3.664 .333 & & \\
Salutacion & 55.840 & 268.755 & 820.443 & & \\
Trinidad & 192.770 & 298.312 & & &
\end{tabular}

b) Valor medio de los juros, en reales de vellón

\begin{tabular}{lrrrrrr} 
& ante 1600 & 1620 & 1640 & 1660 & 1680 & 1700 \\
\cline { 2 - 7 } S. Basilio & & 6.573 & 582 & & 2.824 & 1.055 \\
Vallecas & 1.503 & 310 & 1.300 & 2.424 & & \\
Trinidad & 447 & 895 & & & & \\
Constant. & 558 & 666 & & & & \\
Sta. Clara & 1.160 & & & & 1.227 & \\
\hline
\end{tabular}


para las que ha sido posible reconstruir de manera fiable y seriada la política de inversiones, pero parece que las fechas cruciales en todos los casos han sido los primeros años del Seiscientos y mediados de ese siglo. Dado que se han incluido los datos de conventos entonces opulentos - agustinos de Santa María Magdalena, trinitarios- y otros que administraban cantidades menos imponentes - Vallecas, Salutación o Constantinopla de franciscanas-y todos se mueven en armonía, está bien justificado suponer que ésa haya sido la dinámica general del uso en las inversiones en deuda pública.

Los capitales así ocupados se doblan para los agustinos y se multiplican para las otras casas entre lo que tenían a principios del siglo XVII y los títulos en su poder en 1625 . Cincuenta años después, los 13.500 rs. de crédito de los mostenses de San Basilio se habían convertido en 1.419.699; las bernardas de Vallecas habían pasado de 311.298 a 687.633 reales de juros comprados en 25 años. A partir del siglo XVIII no aparecen ya avances tan espectaculares en la adquisición de juros, pues los de Santa Catalina y los de Santa Clara se mantienen estables en la segunda mitad del siglo, al igual que los del Carmen entre 1725-175; en cambio este convento había más que doblado sus capitales situados en la centuria de 1650 a 1750 . El mismo estancamiento se advierte también, por último, en el caso de San Felipe Neri.

Lo que en todo caso es evidente, es la ingente cuantía de títulos de deuda pública en manos de los regulares. Se ha podido realizar también la tabulación de los valores medios de los juros adquiridos por algunas casas, en el apartado b) de la misma tabla, pero la naturaleza tan errática de los datos no permite sacar conclusiones sobre tendencias globales, si no es que las diferencias entre conventos se ponen de manifjesto también en este apartado, pues había institutos que gastaban en juros un valor medio mucho más elevado que otros. Con mucha prudencia pues los datos disponibles son muy parciales, se puede tal vez hipotizar un crecimiento tendencial del valor medio de los títulos comprados, paralelo al avance del siglo XVII.

\section{Censos.}

La actividad principal de los monasterios en el campo económico, en el siglo XVII al menos, no era la pasiva de perceptores de renta por deuda pública, sino que desarrollaban una función activa y dinámica en el mercado crediticio mediante su práctica habitual de conceder préstamos con garantías hipotecarias, los llamados censos.

El recurso a esta actividad fue tradición de los regulares durante todo el Antiguo Régimen, hasta el punto de ser, en el mundo rural, prácticamente ex-

La época de Felipe II y los Austrias

Hispania Sacra 50 (1998) 
clusivo de los religiosos ${ }^{13}$. Para el prestador, el censo representaba la doble ventaja de asegurarse una renta fija, lo que de por no sí era un aspecto siempre entusiasmante, dado el bajo tipo de interés que las medidas de la Corona habían fijado en varios decretos, y sobre todo de acrecentar el patrimonio porque la garantía hipotecaria sobre la que se fundaban permitía adquirir bienes raíces con sólo seguir una paciente espera hasta que los deudores morosos hubieran acumulado una deuda insalvable y actuar entonces judicialmente contra ellos y hacerse con el bien hipotecado. De eso estaban bien enteradas las autoridades, pues desde los años sesenta del siglo XVIII ya habían menudeado las críticas al sistema de monopolio en el crédito de que gozaban los regulares. En Madrid los censos perpetuos se habían mandado reducir a otros al quitar por orden del Consejo en 1770 a causa de los quebrantos en las economías de los vecinos de la Corte.Y, no por casualidad, esos años del Setecientos coinciden con las fechas indicadas por Fernández de Pinedo como el principio del abandono de los préstamos hipotecarios ${ }^{\mathrm{i4}}$.

La cuantificación de los capitales dedicados a inversiones en censos plantea las mismas dificultades que para los juros. Los cálculos siguientes son por lo tanto prudenciales en cuanto que han sido realizados sobre la base de un tipo de

13 E. FERNÁNDEZ DE PINEDO, Del censo a la obligación: Historia agraria de la España contemporánea, I, Barcelona 1985, pp. 298-299; ATIENZA LóPEZ, op. cit. p. 123. Véanse también La Historia social de Galicia en su fuentes de protocolos, ed. E. EIRAS ROEL, Santiago 1980; M. VAQUERIzo GiL, Los censos al quitar, nueva fuente para el estudio de la financiación: Revista del Centro de estudios Montañeses, I, 1975.

14 Real Despacho sobre censos perpetuos en Alcalá, 25/XV/1772; Auto Acordado 5/1V/1770, sobre censos en Madrid; FERNÁNDEZ DE PINEDO, op. cit. pp. 300-301. Las quejas de Pedro Rodrígucz, personero del común đe Alcalá de Henares, son elocuentes:

"[...] por hallarse los edificios de que se componía y adornaba la Población de aquela Ciudad amenazados con diferentes Censos perpetuos a favor de distintas comunidades [...] en grave e irrecuperable dispendio de el público de dicha Ciudad, hornato y hermosura della por consistir y vincularse en la subsistencia de sus avitantes y edificios mediante la demolizion y ruina que de ellos se experimentaban proveniente este dafio de que los deudores y tributarios de los censos teniendo presente el perjuicio que sufrian en su perpetuo canon no procedian con la maior bijilancia a subvenir ni contener la quiebra de sus Casas a lo que también concurría la indigencia y miseria de los vecinos [...]".

Los gobernantes no podían quedar insensibles ante tal pintura de la situación e inmediatamente, con Real Despacho de 1772 se reducía el interés đe los censos al $2 \%$, prohibiéndose también la institución de doble laudemio en favor del poseedor del dominio directo y del comprador, en suma se mandaban aplicar en Alcală las medidas tomadas para Madrid en el Despacho sobre Censos de 1763 y en cuyo dispositivo se achacaba a los religiosos la ruina urbanística de la Corte,

"superiormente siendo aquellos [los censos perpetuos] a favor de manos muertas en quienes se perpetuaba la propiedad de los edificios que se apropiaban por tan extraño título".

Ese Auto, en su artículo IX, dictaminaba en efecto que, dado que las manos muertas no podian adquirir bienes sometidos a censos perpetuos por derecho común, tales propiedades debían ser devuettas y desvinculadas, por nulidad radical de la adquisición; aunque la práctica demuestra que no era aplicado, deja constancia del conocimiento del fenómeno y de sus efectos. 
interés constante del $3 \%$, evidentemente demasiado bajo para los períodos más antiguos, pero que sirve para reconstruir la masa de capital colocado en prácticas hipotecarias en la ciudad de Madrid, dejando siempre bien sentado que se tratará de estimaciones por defecto, pues los intereses de los censos sufrieron en el curso del tiempo algunas intervenciones reguladoras por parte de la Corona para reducir constantemente su cuantía.Por ejemplo, de los 29 contratos de las agustinas calzadas de Santa María Magdalena en el siglo XVI, el interés oscilaba de un mínimo de $2,8 \%$ a un máximo de $11,87 \%$ o incluso a un $11,93 \%$ en una escritura de 1593. El interés medio global se movía en tomo al $7 \%$ y con un tipo tan elevado quedaba garantizada una muy buena rentabilidad para ese tipo de empresas, tanto más en cuanto que el período histórico en que se realizaban no tenía una inflación comparable con la de los dos siglos siguientes. El hecho de que se aceptaran créditos en condiciones tan gravosas para el tomador pone en luz las necesidades acuciantes de algunos sectores de la población madrileña, desquiciada por la presencia de la Corte y el proceso de implantación de la capitalidad ${ }^{15}$.

Uno de los aspectos más interesantes de esta realidad es el drenaje de capitales que las instituciones religiosas efectuaban del campo a la ciudad, pues algunos conventos tenían una presencia muy arraigada en el mundo rural mediante la concesión de créditos a campesinos y labradores, tanto que difícilmente pudiera ser casual, sino que respondía a una práctica bien establecida. Es tal el caso de las franciscanas menores observantes de Santa Clara, quienes administraban a mediados del Seiscientos más de 600.000 reales en censos. Antes de finales del XVI habían invertido en Madrid 153.024 rs. y en el campo 12.892; veinticinco años después el capital dedicado a censos en la Corte se había duplicado, pero el invertido en el campo había crecido más de diez veces, alcanzando los 191.124 rs. y los créditos a campesinos representaban la mitad del capital invertido.

Las series contables de algunos de estos conventos son excepcionalmentericas y completas, por lo que, junto con los datos de tendencia global, algunos institutos serán presentados como ejemplos más ilustrativos. Por ejemplo es mención obligada el monasterio de San Martín, del que se han seguido 207 contratos de censo entre finales del Quinientos y del Setecientos, y de los que 182 , o sea un porcentaje muy significativo, pueden ser fechados. A pesar de ser una institución de grandes tradiciones y antigüedad, el monasterio de San Martín no dedicaba a préstamos demasiados capitales, al menos en comparación con otros conventos, pero el dato más significativo es la evolución de esa práctica, porque en el primer cuarto del siglo XVIII invirtió en censos una

is Y la coyuntura económica general. "Un trasvase de rentas del ámbito laico al eclesístico, que debi6́ alcanzar en el siglo XVII su mayor dinamismo y que pone de manifiesto la crisis por la que estaban atravesando las economías de particulares, configuró a los regulares como uno de los principales gnupos acreedores". ATIENZA LÓPEZ, op, cit. p. 123.

La época de Felipe II y los Austrias

Hispania Sacra 50 (1998) 
cantidad superior al total de lo invertido hasta aquel momento, y mantuvo ese ritmo durante la primera mitad de la centuria. De tal modo se formó un capital de 149.133 reales de crédito en 1750, cuando eran menos de 30.000 en 1600 .

\begin{tabular}{|c|c|c|c|c|c|}
\hline Convento & 1600 & 1650 & 1700 & 1750 & 1800 \\
\hline S. Martín & 29.266 & 36.933 & 40.333 & 149.133 & 185.700 \\
\hline Magdalena & 60.856 & 143.331 & & & \\
\hline Recoletos & & & & 405.000 & \\
\hline S. Felipe R. & & & & 767.833 & 1.072 .533 \\
\hline S. Basilio & & 42.166 & 262.066 & 409.563 & \\
\hline Vallecas & 150.271 & 691.496 & 895.660 & 2.314 .820 & \\
\hline Carmen & & 998.563 & & 717.766 & \\
\hline S. Felipe N. & & & 321.300 & & 230.866 \\
\hline S. Catalina & 230.012 & 545.016 & 932.128 & 932.128 & 932.128 \\
\hline Salutación & 55.440 & 163.020 & 253.900 & & \\
\hline Trinidad & 251.044 & 583.641 & & & \\
\hline S. Clara & 165.916 & 646.199 & & & \\
\hline S. Norberto & & 92.913 & 215.041 & 226.622 & \\
\hline
\end{tabular}

Estos datos vuelven a arrojar luz sobre las diferencias de la riqueza entre conventos, pero esta faceta no merecería más atención pues se trata de una realidad de sobra conocida. En cambio ofrecen unas interesantes indicaciones

TABLA 3. Valor medio de los censos en favor de los conventos, en reales de vellón.

\begin{tabular}{lcrrrrrrr} 
& ante 1600 & 1625 & 1650 & 1675 & 1700 & 1725 & 1750 & 1775 \\
\cline { 2 - 8 } S. Martín & 9,5 & 98,5 & 42,6 & & 14,6 & 103,5 & 375 & 219 \\
Magdalena & 241,3 & 370,1 & & & & & & \\
S. Basilio & 174 & 152,4 & 475,3 & 444,1 & & & & \\
Vallecas & 275,6 & $2.946,9$ & $3.764,5$ & 3.242 & & & & \\
S. Catalina & 255,7 & 274,5 & 296,2 & 507 & 387,5 & 190,7 & & \\
Constant. & 693 & 206,6 & 449,6 & 174 & 1.049 & & & \\
S. Clara & 73,9 & 138,8 & 396,2 & & & & & \\
S. Norberto & $4.035,6$ & 8.866 & 5.688 & 24.443 & & & & \\
\hline
\end{tabular}


si se los compara con los valores homónimos de los juros, porque, exceptuando los dos conventos de las Vallecas y de San Norberto, todos los demás tienen valores medios muy inferiores para los censos. Esto, junto con el hecho de que se invertían más capitales en préstamos que en títulos de deuđa pública, indica a las claras que los religiosos preferían dedicarse a pequeños contratos, o sea, trabajar con gente humilde, y no última razón de ello debía ser, como ya apuntaba Atienza López, el que ésta estaba más desvalida en caso de actuar contra ella. Las indicaciones de la tabla también marcan otra diferencia con la de los juros en que no parece apreciarse ningún crecimiento tendencial en el valor medio de los censos a lo largo del período estudiado, con la salvedad del caso de los premostratensess de San Norberto, pero por ser un dato aislado, y por lo extremo de su cuantía, cae en el grupo de los casos particulares.

Los tipos de interés eran bastante bajos, y aunque por una parte eran una amenaza para las rentas cobradas, por otra servían para conseguir los capitales precisos para financiar las actividades de los conventos a precios asequibles. Así en 1754, "que con motibo de hallarse en la grabe notoria Vigente precisión y necesidad de comprar trigo para su indispensable subsistencia, y sin tener al presente fondos ni medios para sufragarla [...]" el abad de San Basilio proponía a su comunidad fundar un censo contra el monasterio por una cuantía de 55.200 reales al $2,25 \%{ }^{16}$. En este caso los monjes tomaban, no daban a crédito. La operación fue realizada con una escritura en favor de los carmelitas descalzos de Balmaseda y San Cirilo de Alcalá de Henares, y para más tarde hacer frente a esta deuda los mismos benedictinos hubieron de pedir otro censo de 44.000 rs. al 2,5\% a la iglesia de San Ginés de la Corte. Para este monasterio el recurso al endeudamiento fue una constante en todo el Dieciocho, sobre todo para financiar la construcción de la fábrica de su iglesia; para este fin se buscaron, y consiguieron, 218.000 reales, todos religiosamente devueltos en algunos años. Como la operación de reembolso de los capitales obtenidos, el rescate del censo, se realizó en breve plazo, hay que pensar que para estos monjes el recurso al crédito no fuera más que una intervención puntual para resolver situaciones coyunturales muy concretas. Las fuentes habituales de financiación de los cenobios eran esencialmente otras.

El caso arriba mencionado trae el problema de la duración de los censos. En teoría, la mayoría de ellos, los llamados censos perpetuos, deberían haber surtido su efecto indefinidamente, mientras que los censos al quitar preveían una cláusula de devolución del capital prestado. Estos segundos eran menos numerosos en la práctica de los conventos, y para los primeros a menudo ocurría que dejaran de ser cobrados, o porque caían en desuso, o porque eran res-

16 AHN, 6921, f. $705 v$.

La época de Felipe II y los Austrias

Hispania Sacra 50 (1998) 
catados, o bien por impago de sus rentas, con la consiguiente acción legal. Sea como fuere, el censo representaba la seguridad de un ingreso fijo durante un período de tiempo bastante largo.

Los archivos del monasterio de San Basilio, el de los monjes endeudados, permiten calcular la media de duración de los préstamos del instituto: 14,8 años, aunque esa duración fue de 43,3 y 30,5 años en los primeros dos lustros del siglo XVIII, como efecto de los desastres de la Guerra de Sucesión. En los períodos siguientes la duración tiende a bajar, seguramente a causa de la situación económica más favorable y a las reducciones en los tipos de interés. Para el siglo XVII se puede recurrir a la serie de los censos del convento de las monjas bernardas de la Piedad, llamadasVallecas. Ahora la duración media de los préstamos era de 33,3 años, pero 14 casos de 63 documentados hablan de censos cobrados durante más de cincuenta años, incluso 5 de 63 con más de ochenta años de antigüedad y dos de más, de un siglo. La moda estadística da la razón a la serie de San Basilio, pues el intervalo de duración media entre 10 y 20 años es el más frecuente, pero sólo en el $23,8 \%$ de los contratos. En cualquier caso, la duración útil del censo, esto es el período de tiempo durante el que era cobrado, se debe calcular alrededor de tres décadas: en efecto, éste era el plazo para más de la mitad $-55,5 \%$ - de los censos de las monjas.

TABLA 4. Duración media de los censos del convento de Religiosas bernardas de Ja Piedad, vulgo las Vallecas, en años, número de casos documentados y porcentajes sobre el total.

\begin{tabular}{lrrrrrrrrrrrc} 
Duración & 5 & 10 & 20 & 30 & 40 & 50 & 60 & 70 & 80 & 90 & 100 & +100 años \\
Casos & 9 & 4 & 15 & 7 & 9 & 5 & 5 & 1 & 3 & 1 & 2 & 2 \\
$\%$ Total & 14 & 6 & 24 & 11 & 14 & 8 & 8 & 1 & 5 & 1 & 3 & 3 \\
\hline
\end{tabular}

Algunos ejemplos, sacados del archivo del monasterio de San Martín, podrán representar graficamente lo que significaba estar sujeto al pago de un censo, obligación que no sólo se extendía durante muchos años de la vida del compromisario, sino que podía surtir efecto también después de su muerte, pues gravaba un bien que podía ser transmitido a terceros. Diego Dama Falcón y María Velasco fundaron un censo de 9.100 rs. de principal y 455 de renta - es decir, al $5 \%$ - en 1702, y dos años después debían reconocer que era para hacer frente a otro - suscrito en 1667- sobre una tierra de 9 fanegas en Vallecas que habían recibido en herencia. La deuda que. habían contraído personalmente debiera haberles servido para pagar un censo que tenía ya casi cuarenta años y que habían tenido que aceptar al recibir la tierra heredada, que les había traído 
más cargas que beneficios. También había reconocido la hipoteca que gravaba desde 1602 el predio que compró José Perdiguero en 1711; del mismo año databa la deuda reconocida por Juan de Urona en 1710. Francisco Femández tuvo que reconoceren 1704 dos censos recibidos por herencia, sobre tierras de viñas de 3 fanegas y 2 celemines la primera y $3 \mathrm{fs}$. $1 \mathrm{c}$. la segunda, y por los que debía pagar cada año respectivamente 229 y 330 maravedíes.La renta se indicaba en moneda ya anticuada porque los censos se remontaban al ... 1568!

Estos títulos de crédito que vagaban en el tiempo eran el escollo donde podía naufragar más de una economía. Fue el caso de Lorenzo Sanz, vecino de Vallecas, en 1770 arrendatario del monasterio, pero hasta ocho años antes dueño de 18 aranzadas de viñas, que hubo de hipotecar y más adelante perder por no poder pagar las rentas del préstamo. De esa manera había bajado de la clase de los propietarios a la de los campesinos arrendatarios dependientes.En efecto, el proceso de expoliación era prácticamente seguro cuando el deudor no podía hacer frente a sus compromisos. Roque Gamir Soldado, también él vecino de Vallecas, ya había tenido que pedir a los monjes un préstamo hipotecando una heredad suya de 3 fanegas y 9 celemines en 1703. Un año más tarde recibió una herencia envenenada, porque junto con los bienes -una tierra de labranza de 5 fanegas en el Arroyo Abronigal- se hizo pagador de un censo de 46 celemines y 1 cuartillo de pan por mitad en nombre de un censo establecido en 1591. Así, el iafortunado? labrador se hallaba a deber 7 fanegas y media anuales por deudas que no había contraído, y para él arrancaba el proceso de depauperización implacablemente cumplido en 1731 con la acción legal promovida por el monasterio, y la consiguiente cesión a los monjes de sus tierras hipotecadas en 1703. Roque Gamir, de edad ya avanzada, se encontraba dueño sólo de la parcela del arroyo Abroñigal que había sido la causa de su ruina, y titular de una deuda que tenía 139 años. Los archivos del monasterio a partir de entonces no dan más datos del hombre y sus circunstancias: con lo que se sabe, la pérdida de status económico del protagonista es evidente.

\section{Patrimonio urbano.}

Lo más llamativo, la distancia entre los datos de cada instituto, reforzando la ya sabida imposibilidad de hablar del estado eclesiástico como un todo económicamente homogéneo, y las diferencias son aún más evidentes si se toma en consideración el doble aspecto de las propiedades urbanas y rurales.Uno de los modos tradicionales de dotar un instituto regular en el momento de su fundación era el de donarle los locales en donde establecerse, y para asegurar las rentas necesarias a su sustento no era infrecuente que se hiciera donación también de otras fincas para que se alquilasen en favor del convento recién funda- 
do. Este es el origen de la propiedad inmobiliaria de los cenobios pero sólo en sus grandes rasgos, pues estos actos de generosidad de los fieles no podrían por sí solos explicar el auge de la propiedad fondiaria alcanzado en los siglos XVII y XVIII, cuando las propiedades de los regulares representaban una parte muy cuantiosa del caserío de la Corte ${ }^{17}$. Por el contrario está claro que los administradores de los cenobios intentaron formar y aumentar su dominio urbano porque el mercado de los alquileres de fincas en Madrid representaba en la Edad Moderna un negocio muy rentable.

La cuantificación exacta del patrimonio inmobiliario eclesiástico en el SeisSetecientos ya ha sido intentada a partir de las estadísticas del Catastro de Ensenada ${ }^{18}$. Más interesante e instructivo para los fines de esta investigación puede ser el estudio de los mecanismos de adquisición del patrimonio, y que se ramificaban en tres ejes básicos. El primero siempre consistió en las donaciones mortis causa, en cuanto demostraciones de la devoción de los fieles en el momento de hacer su testamento o en algunas ocasiones como donaciones inter vivos siempre motivadas por la fe. Los otros dos modos de adquisición de bienes no seguían consideraciones religiosas sino las leyes de la economía mundanal y consistían en las adquisiciones a título oneroso, esto es una inversión directa en predios urbanos o rústicos, generalmente realizada con los activos de caja, o en otras ocasiones por ejecución judicial de las deudas acumuladas y no pagadas, y es aquí donde los censos hipotecarios toman una importantísima doble función en las economías monásticas porque por una parte garantizan una renta anual constante y segura, y su bajo interés estaba equilibrado por la posibilidad de convertirse en el instrumento para obtener la titularidad del bien gravado ${ }^{19}$. Los registros contables de los institutos no han conservado todos los títulos de propiedad de los conventos, pero los archivos dan las indicaciones suficientes para reconstruir las grandes líneas de la realidad global. De nuevo los benedictinos de San Martín serán el ejemplo esclarecedor, con su monasterio entre los más prósperos de Madrid.Durante el siglo

\footnotetext{
17 Caro López, Casas y alquileres ... cil.

"Para la exacción del excedente la lglesia no necesitaba recurrir a la compulsión, sino que era la misma piedad de los fieles la que hacia fluir hacia ella, como limosnas, parte dela riqueza circulante, tanto en especie como en metálico, y parte del capital inmobiliario bajo la forma de propiedades tanto rústicas como urbanas". LópEZ MARTÍNEZ, op. cit. p. 17.También GALBís BLANCO, op. cít. p. 811, para cl caso valenciano de Ara Christi.

18 Matilla Tascón, op. cit.

19 ATIENZA LóPEZ, op. cit; FERnÁNDEZ DE PINEDO, Coyuntura ...cit., p. 65, a propósito del aumento de tierras sometidas a vínculo durante el siglo XVIII:

"la mayor parte de estos nuevos vinculos se formaron merced a la compra de parcelas de campesinos endeudados, a quienes previamente se les habia prestado dinero y que, incapaces de hacer frente al pago de los intereses, tuvieron que vender sus tierras".
} 
XVIII promovieron no menos de 32 acciones judiciales, todas motivadas por el impago de deudas y cuya naturaleza era la siguiente:

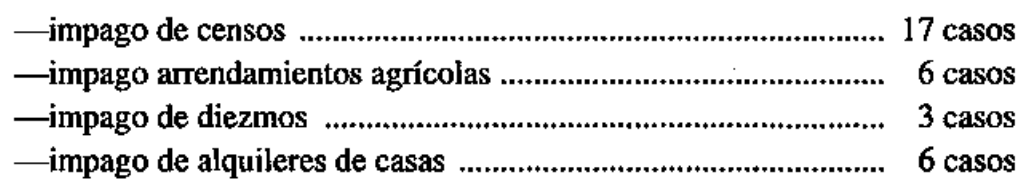

Es muy indicativo notar cómo el valor medio global durante el siglo XVIII de estas deudas fue de $1.856,2 \mathrm{rs}$. lo que significa que por una cantidad relativamente modesta los acreedores podían apropiarse legalmente de unos bienes hipotecados de valor evidentemente más elevadoy a la vez se nota que los regulares preferían actuar antes contra los humildes que contra los poderosos, a quienes era más difícil llevar a juicio, como ha señalado Atienza López también para Zaragoza.

La morosidad también está relacionada con la coyuntura económica general, lo que indica que los cenobios conseguían mejores beneficios en este campo, o eran menos dañados que la sociedad civil en tiempos de crisis - si se exceptúa la Guerra de Independencia, donde a motivos de índole catastrófica-destrucciones, expolios, muertes - se unieron las medidas desamortizadoras de José I. Por ejemplo, según las series de San Martín, de 33 casos fechados de acciones para realización de bienes en garantía de censos hipotecarios no pagados, 12 pleitos tuvieron lugar entre 1700 y 1712 , y otros 9 en los diez años siguientes. Otro indicador de la misma realidad puede ser dado por el movimiento medio de las deudas; en los primeros diez años del Setecientos eran de $2.636 \mathrm{rs}$, reducidos a 2.379 en los diez años siguientes, pero mucho más elevadas que en el resto del siglo, como muestran los datos relativos a períodos de diez añosdel siglo XVIII. Lamentablemente no se pueden reconstruir los treinta años de 17501780 , por falta de datos concretos, pero los disponibles son lo bastante elocuentes como para entender que el índice de morosidad resultaba más elevado en el período contemporáneo e inmediatamente siguiente a la Guerra de Sucesión mientras que la situación mejoraba para los deudores y se estabilizabaen niveles mucho más bajos a lo largo del siglo, para volver a subir en vertical con los diez áltimos y trágicos años del Siglo de las Luces :

\begin{tabular}{lllll} 
—años 1701-1710, valor medio de las deudas & \multicolumn{2}{c}{2.636 reales } \\
—años 1711-1720, “ & " & “ & 2.349 “ \\
—años 1721-1730, “ & “ & 4 & 522,6 “
\end{tabular}

La época de Felipe Il y los Austrias

Hispania Sacra 50 (1998) 


\begin{tabular}{|c|c|c|c|c|}
\hline 一años 1731-1740, & "ब & " & " & 1.386 \\
\hline —años 1741-1750, & “ & “ & “ & 888 \\
\hline -ä̃os 1771-1780, & " & “ & “ & 467 \\
\hline 一años 1781-1790, & $"$ & $"$ & “ & 467 \\
\hline —años 1791-1880, & “ & « & “ & 2.250 \\
\hline
\end{tabular}

Si la media global de todas las deudas fue de $1.856,2$ reales durante el siglo, significa que sólo en tres momentos se superó ese valor, a los comienzos y al final de la centuria.

Una vez más los archivos de San Martín indican hasta qué punto las actividades económicas del monasterio eran de naturaleza monetaria, y de hecho sólo siete casos de 33 acciones judiciales se refieren a deudas en especie, y de éstas cinco en los primeros veinte años del Setecientos. Los registros del monasterio también dan numerosos ejemplos de cómo era la práctica judicial. En 1711 los monjes adquirían en Fuente el Fresno, de Pedro Aguado Perdiguero, una tierra de dos fanegas a raíz de una acción promovida en 1703, por el impago de un arrendamiento a real por fanega. La lentitud de la justicia no hacía sino volver más inexorable la aplicación de las disposiciones judiciales. Si el primer caso había durado ocho años, Atanasio Vilón denunciado por sus deudas de 2.580 reales en 1705 fue condenado a pagar con intereses y gastos, en 1730 , casi el doble, 4.900 reales. Las deudas se sumaban a los intereses y ayudaban a ahogar cada vez más a los deudores insolventes. Los herederos de Sebastián Crespo, de Fuencarral, en 1705 habían sido condenados a resarcir con una tierra de 44 fanegas y 100 pies de viñas una deuda de 522 reales por impago de un censo de 55 reales anuales. Los monjes habían esperado cerca de diez años para iniciar su acción, y además al momento de dictar sentencia se exigía a los herederos del moroso el pago de 3.200 reales de intereses y costos procesales, es decir seis veces la deuda acumulada y sesenta veces la cuantía del censo. Las víctimas de este engranaje fueron por lo tanto desposeídas de su bien y los antiguos propietarios se convirtieron en arrendadores del monasterio. Pero ni así su situación era sostenible y cinco años después fueron nuevamente acusados de no haber pagado nuevas deudas, y ahora debían otros 1.100 reales más gastos. Así, en un proceso de imparable depauperización, perdieron en favor de los benedictinos otras dos tierras y un majuelo valorados en 2.240 rs. Los monjes más tarde venderían una de las heredades en 1.388 reales, haciendo un negocio redondo, pues se habían hecho dueños de varios fondos rústicos por el valor de una deuda de 1.622 reales, cuando un sólo predio ya valía casi la totalidad de la suma impagada. Este ejemplo pone de manifiesto lo lejos de la realidad que estaban las tasaciones de los bienes hipotecados cuan- 
do se trataba de fallar en favor de los acreedores e incluso es probable que se tratara de un valoración interesada pues los expertos que debían formularla eran algunos entre los vecinos más conspicuos del lugar, quienes evidentemente tendían a no enemistarse con los poseedores de los capitales. Es el mismo caso que ocurrió a los derechohabientes de Gabriel Bamuevo, muerto en 1726, denunciados en ese mismo año por una deuda de 37 fanegas de trigo a 15 rs. la unidad. La suma debida total era por lo tanto de 415 reales pero el monasterio recibió como compensación dos predios de 2 y 1 fanegas respectivamente valoradas en 2.200 reales. La diferencia entre la suma debida y el valor pagado aunque incluye los interese y gastos del proceso puede también indicar que los peritos encargados de la tasación de los bienes hipotecados estaban influidos por la importancia de los acreedores. Lo que es innegable es que así se pone de manifiesto la voluntad clara constante y consciente de formar o ampliar el patrimonio fondiario de los religiosos, y aunque es imposible determinar las cuantías exactas de las adquisiciones judiciales, en el curso del siglo XVIII los benedictinos de San Martín reflejan en sus libros la adquisición de al menos cuatro casas en la ciudad y 153 fanegas y 5 aranzadas entre tierras de labranza y viña. A la vista de estos hechos es muy relativo hablar de la benevolencia de la administración religiosa para con sus clientes, porque no se puede saber si el permitir que se acumularan durante tantos años los impagados de rentas y censos se hacía por generosidad o porque así se esperaba alcanzar un nivel de endeudamiento que llevara a la expropiación del bien garantía y su adjudicación al convento, conquistando un patrimonio inmobiliario con un elaborado ceremonial de posesión:

la qual le dio Quieta y Pazificamente [el alguacil al procurador del monasterio] y en señal de ella le tomó de la mano y entró en dicha tierra donde rancó terrones y los tiró y despojó los que en ella estavan.

Otras veces los "actos posesorios" consistian en "arrancar diferentes yerbas y demoler muchos terrones". Y se puede hablar de "conquista", pues, según Reynolds, la toma de posesión de Méjico por parte de Cortés ocurrió según "una ceremonia interesante", a saber

Cortés mandó hacer alto a los soldados, y dexando el cavallo en que venía, tiró piedras, y yervas arrancando, la posesión por Carlos fue tomando 20 .

20 HÉRR, La hacienda ...cit, p. 22, describe una ceremonia parecida. AHN, 8546 , f. 547 y $5845 \mathrm{f}$ 473, ambos de 1705. Los versos son de Saavedra, citados por W.A. REYNOLDS, Hernán Cortés en la liveratura del Siglo de Oro, Madrid 1978, pp. 148-149. La economía parece ser, cada vez más, la continuación de la guerra con otros medios.

La época de Felipe II y los Austrias

Hispania Sacra 50 (1998) 
Esas prácticas eran la tónica habitual en todos los institutos como indican sus registros. San Norberto de Premostratenses actuaba en 1650 contra Antonio Salinas por censos no pagados y garantizados con "tierras viñas y olivares" y "casa principal y su bodega" en Valdilecha una vez que la renta anual de 286 rs. debida al convento se había transformado en 1.292 rs. desde 1642 . En el mismo año era desahuciado D. Juan de Zárate de "unas Casas principales calle de las espaldas de las Siete Chimeneas" por otra deuda parecida. Diez años habían servido a los frailes para hacer ejecutar la hipoteca fundada en 1651 por Mateo de Batres cuando los 1.084 rs. de censo anual habían generado una deuda de 10.996 con los intereses. En este caso los religiosos conseguían la titularidad de ciertas heredades, y así queda de manifiesto la rentabilidad de los censos, no por las rentas que proporcionaban sino por las puertas que abrían para la adquisición de propiedades inmobiliarias gracias a la morosidad de los contrayentes.

\section{Bienes rústicos.}

Una parte de los capitales de los conventos estaba destinada a producir intereses por rentas fijas en censos y juros, pero la riqueza de los institutos regulares de Madrid es dada también por sus predios rústicos y fincas urbanas, los primeros buscados a causa de la demanda siempre creciente de productos agrícolas y el consiguiente aumento de precio de los mismos durante el siglo XVIII, los segundos por la buena inversión que representaba la vivienđa en la Corte por la demanda de alojamientos y los niveles de alquileres. Ya es sabido que los patrimonios de los cenobios eran muy distintos entre sí, al igual que su presencia en la ciudad o en el campo. El monasterio de San Martín, una vez más el indicativo, poseía en el siglo XVIII $174 \mathrm{fs} .6 \mathrm{cs}$. de tierra en Vallecas, 49 en Fuente el Fresno, 63 fs. en Canto Blanco, 30 en Cobeña, 174 en Alcobendas y 412 fs 2 cs. en Fuencarral, por un total, según el apeo, de 904 fanegas en tierras de labranza. En 1713 los agustinos recoletos de San Agustín tenían siete casas y $263 \mathrm{fs}$. de tierras de labranza, 75,5 aranzadas de viña con 7.319 cepas y 262 pies de olivos; los agustinos de San Felipe el Real poseían 47 fanegas de tierra, 64 aranzadas y 15 predios de viña, y otros 29 fondos de olivares en Illescas, Colmenar de Oreja, Pozuelo de Tajo y Chinchón, por un valor total de 560.410 rs. A finales del Seiscientos, los premostratenses de San Basilio tenían 18 casas pero los registros no mencionan bienes raíces en el campo, mientras que las monjas bemardas de la Piedad, las Vallecas, tenían $270 \mathrm{fs}$. y media en Vallecas. Todos los apeos y registros de este convento insisten en la sustancial inmovilidad de la propiedad de tierra a partir del primer cuarto del Seiscientos, cuando se formó su núcleo central de 264 fanegas. Los documentos 
señalan en cambio la continua lucha entre los propietarios con sus arrendatarios para evitar usurpaciones, posibles por la lejanía de las amas y que se refleja en las oscilaciones de la superficie registrada: $264 \mathrm{fs}$. en 1628, 213 en 1634, y cuatro años más tarde otra vez la cifra inicial, a raíz de un nuevo apeo realizado por las monjas alarmadas ante la erosión de su patrimonio. Los clérigos menores de Portaceli-San Felipe Neri tenían en el último cuarto del siglo XVIII veinte casas en la Corte, cinco en Arganda y 28,14 aranzadas de viña en el mismo lugar, con 11.257 cepas. Las tierras de labranza de las franciscanas menores de la Purísima Concepción, 240 heredades con 876 fs. de superficie global en 1790, estaban estratégicamente situadas en los alrededores de Madrid: Alcobendas, Coslada, Getafe, Vicálvaro, Carabanchel, Leganés - 157 fs. - Húmera y Pozuelo - 157-, Torrejón de Ardoz, donde se concentraba el grueso de sus bienes, con 333 fs. La riqueza en la documentación sobre la explotación de esos bienes ofrece también interesantes series sobre aceite, vino y granos producidos y vendidos, merecedores de un estudio pormenorizado y que sería muy indicativo para la historia agraria en Madrid. Otras casas se especializaban o concentraban sus inversiones en lugares concretos, como las franciscanas menores observantes de Constantinopla, quienes tenían en 1706 13 casas y un molino en Rejas. San Joaquín de mostenses, según su apeo de 1686-87 tenía 18 casas en la ciudad y 6 heredades en Pinto, de las que se ignora la superficie, y $191 \mathrm{fs}$. en Boadilla. Bastante más rica la comunidad de clarisas de Santa Clara, en 1785, con sus 851 fs. de tierra y 36 casas en Madrid, menos que las dominicas de Santa Catalina de Sena, quienes tenían 49.

Del conjunto de los números arriba expuestos se pueden sacar algunas consideraciones globales. La primera, la cuantía no indiferente del patrimonio inmobiliario registrado en los libros de cuentas de los monasterios. Tal vez más interesante sea comprobar las dimensiones medias de las heredades de los re-

TABLA 5. Superficie media de las fincas rústicas de algunos conventos madrileños, en el siglo XVIII.

\begin{tabular}{|c|c|c|c|c|}
\hline & \multirow{2}{*}{$\frac{\text { TIERRAS }}{\text { fanegas }}$} & \multicolumn{2}{|c|}{ VIÑAS } & \multirow{2}{*}{$\frac{\text { OLIVOS }}{\text { árboles }}$} \\
\hline & & aranzadas & cepas & \\
\hline S. Agustín & 5,72 & 1,77 & 211 & 14 \\
\hline S. Martín & 15,30 & & & \\
\hline Vallecas & 2,45 & 3,51 & 1.707 & \\
\hline Concepción & 3,65 & & & \\
\hline Salutación & 9,96 & 1,5 & & 90 \\
\hline S. Joaquín & 9,00 & & & \\
\hline
\end{tabular}

La época de Felipe II y los Austrias Hispania Sacra 50 (1998) 
gulares, que aunque se abrían en un abanico de 1 a 6 , de las 15,3 fs. de San Martín a las 2,45 de las Vallecas, indican dimensiones más bien reducidas, y por lo tanto fácilmente administrables.

Apuntes sobre las relaciones propietarios-arrendatarios.

La administración de las propiedades urbanas se limitaba al cobro de los alquileres y a hacer frente a los gastos de reparación de los inmuebles cuando las circunstancias lo exigían, junto claro está con el pago de los tributos y regalías sobre las casas. La explotación del patrimonio agrícola implicaba un planteamiento y un conjunto de relaciones económicas más complejos. Durante el siglo XVIII se verifica un incremento tendencial de las rentas agrícolas por una serie de razones de sobra conocidas: la población española crece de manera sostenida por lo que también aumenta la demanda de productos agrícolas; ello acarrea también el alza del valor de la tierra en cuanto factor de producción, con varias maniobras de ataque a la propiedad comunal, a los baldíos, y con la puesta en cultivo de tierras marginales. Con estos ingredientes la receta para los propietarios de tierras era de endurecer las condiciones contractuales de arrendamiento en su favor, pues el alquiler de predios agrícolas se consideraba por parte de los terratenientes como el sistema más adecuado para obtener beneficios sin efectuar inversiones ni arriesgar capitales; tanto es así que la corona se encontró en la situación contradictoria de haber emanado una Real Cédula para sancionar la libertad total en la estipulacición de arrendamientos agrícolas, en 1770 , es decir, dejando las manos libres a los propietarios de la tierra, de una parte, y de otra, ser requerida por los arrendadores que se lamentaban a causa de las condiciones cada vez más duras de sus contratos para que interviniera a mitigarlas ${ }^{21}$.Y la manera más sencilla de controlar a los colonos consistía en regular la duración de los arrendamientos ${ }^{22}$. En el País Valenciano, esos contratos nunca eran superiores a los diez años, para evitar que el colono pudiera adquirir derechos sobre el predio; la duración media era de seis años. Los libros de cuentas de la bernardas de Vallecas y de San Martín permiten fijar un modelo para Madrid en los siglos XVII y XVIII que no arroja ninguna diferencia sustancial en la duración de las escrituras; para el Seiscientos eran prácticamente de nueve años, y ligeramente más bajos en el siglo siguiente.

21 Real cédula 26/V/1770. Fernández DE PINEDO, Coyuntura ... cit, p. 67; CALLAHAN, op, cit. p. 52; un modelo interesante de funcionamiento de la economía campesina, en KAMEN, op. cit. pp. 160 ss.

22 Sobre la duración de los contratos, ARTOLA, Propiedad ... cit, pp. 42 ss; la situación segoviana, muy semejante a la de Madrid, en BARRIO GOZALO, Estudio ... cit, p. 627 y Los conventos ... cit, p. 641; las fincas del convento de San Esteban de Salamanca no se arrendaban tampoco por más de nucve años consecutivos, según MARTín MARTíN, pp. 579-581. 
TABLA 6. Duración media de los arrendamientos agrarios, en años. Por períodos decenales, siglos XVII y XVIII.

\begin{tabular}{lrrrrrrrrrr} 
Años & 110 & 120 & 30 & 40 & 150 & 160 & 70 & 180 & 90 & 199 \\
XVII & 8,8 & & 8,8 & 9 & 9 & 9 & 9 & & & \\
XVIII & 5,3 & 8 & 7,8 & 5,6 & 6,2 & 7 & 8,5 & 8,3 & 8 & 8 \\
\hline
\end{tabular}

En el Diecisiete, la duración de los contratos, de nueve años, era un plazo relativamente largo, y puesto que las condiciones de pago estaban fijadas desde el primer momento, se daban las condiciones para que el arrendatario intentara aumentar la productividad de su tierra pues iría en beneficio suyo. En este período la política de explotación agraria apuntaba en la dirección de fijar al trabajador en la tierra ofreciéndole condiciones de trabajo y de vida favorables. El libro 7217 del convento de la Piedad da la posibilidad de seguir a los titulares de los arrendamientos de las tierras de las monjas de 1621 a 1674, y los casos en la dirección ahora reseñada son evidentes.

Juan Redondo, por ejemplo, emprendió un contrato de nueve años en 1621, al precio de seis fanegas de trigo, que se le prorrogó hasta 1630 por siete fanegas, precio mantenido en la tercera prórroga de otros nueve años; en 1641 lo sustituyó su viuda Melchora de Cobo, pagando ocho fanegas, mismo precio estipulado para la renovación de 1649.En total, los mismos titulares habían trabajado el mismo fondo durante 48 años con unas rentas que habían subido de seis a ocho fanegas de trigo, o sea un $33 \%$, o lo que es lo mismo, menos de un $1 \%$ anual.

Más larga aún la relación de los Velasco con el administrador de las monjas. La empezó Francisco Alonso en 1621 comprometiéndose a pagar 27 fanegas de trigo; al final del primer plazo, en 1630 , renovó por 28 , un aumento muy moderado, del 3,7\% en diez años, y en 1641 pagaría todavía sólo 29. De nuevo renovación de contrato, en 1650, y nueva subida del cánon de arrendamiento, de una fanega más. Es decir, para dos períodos de diez años, la subida del arrendamiento había sido primero de un 3,5\% y después de un 3,4\%. Francisco Alonso Velasco fue titular del contrato durante 38 años, hasta que en 1660 lo sustituyó Lucas, su hijo, pagando entonces 30 fanegas por las mismas heredades. En conjunto, esta familia trabajó durante dos generaciones en las mismas tierras y los valores de la renta habían crecido en todo el período en un tercio, de 27 a 30 fanegas.

El inmovilismo de las relaciones se manifiesta también con la inercia de la presencia de las mismas familias en los contratos de arrendamiento, pues distintos grupos familiares llevaron durante el Diecisiete las tierras de la Piedad durante varios años seguidos o durante más de una generación. Ante un plazo

La epoca de Felipe II y los Austrias

Hispania Sacra 50 (1998) 
medio de arrendamiento de nueve años en su conjunto, 23 casos hablan de grupos familiares que labraron las mismas tierras durante una media de 26,2 años, con tendencia más pronunciada a las duraciones más largas hacia la segunda mitad del siglo:

TABLA 7. Duración media, en años, de ocupación de las mismas fincas por parte de las mismas familias.Siglo XVII.

\begin{tabular}{lcccccc} 
Período & 1610 & 1620 & 1930 & 1640 & 1650 & +1650 \\
Años & 7,4 & 18,5 & 27,5 & 37,7 & 50 & 56 \\
\hline
\end{tabular}

Para el siglo XVIII, el archivo del monasterio de San Martín da la pauta: con casos como el de Juan de Uroa, en 1711, arrendatario de 44 fanegas de tierra de labranza por 24 fanegas de grano de renta; en 1717, al término de su primer contrato, repetía pero ampliando el alquiler a algunas viñas en Alcobendas, y por cánon debía pagar 30 fanegas de granos y 100 reales anuales, por otros ocho años. De este colono no se vuelve a tener noticia, pero es posible seguir los pasos de otros agricultores, como D. Francisco de Espinosa y Barredo, documentado entre 1715 y 1746, siempre llevando 9 fanegas de tierra por una renta de 6 fanegas de trigo, aumentadas a 7 en el último contrato de 1746 y de duración de sólo cuatro años. Este vecino de Torrejón de Velasco había tomado el arrendamiento de este predio en 1725 junto con unas viñas "de muy mala calidad" por 1 fanega de trigo anual, en ocho años, con el objetivo evidente de mejorarlas con su trabajo. Este colono labró las tierras del monasterio durante treinta años por lo menos, y en un contrato de las mismas tierras fechado en 1756 se encuentra como tenedor otro Espinosa, también vecino de Torrejón, sin que se sepa si era hijo - como parece probable_- de aquel, y por precio de 7 fanegas de grano. Es decir, que entre 1715 y 1756 el predio se había arrendado con una subida de sólo 1 fanega de 6 iniciales (aumento del $16 \%$ en 40 años). El hijo del segundo arrendatario, D. Antonio, se encargó a su vez del mismo fondo en 1768, por ocho años y con la misma renta; abuelo, padre e hijo de la misma familia formaron de esta manera una relación económico familiar que se extendió durante sesenta años ${ }^{23}$. No hay en los archivos otros ejemplos de tan larga duración entre los arrendatarios, pero eso no indica que no se prodigaran los casos de "fidelidad" para con el propietario - ¿o sus fincas? Más bien parecería lo contrario, estando a las experiencias de Pedro Parejón, colono de 5 fanegas 10 celemines de labranza en

${ }^{23}$ AHN, 7215, 7217, 7216. 
Vallecas, él y sus descendientes, por lo menos desde 1776 hasta 1796 , con una renta de 6 fanegas de pan al principio y sólo 5 doce años después. También mejoró sus condiciones de arrendamiento Pedro Calleja entre 1789 y 1807 pasando de pagar 7 fanegas de trigo en su primer contrato a 6 en el segundo, fechado en 1799. Lo más curioso en este caso concreto no es la rebaja en el cánon, sino que el labrador había sido anteriormente denunciado por los monjes por los retrasos en el pago de las rentas, por lo que el hecho de que se le renovara el contrato a un moroso, y con mejores condiciones económicas por añadido, tal vez pudiera indicar una falta de mano de obra dispuesta a dedicarse al trabajo agrícola en los últimos años del Dieciocho, años de dramática coyuntura por cierto, o tal vez sean el reflejo - las dos hipótesis no se excluyen, sino que se complementan - de las crisis de producción de finales del Antiguo Régimen.

El caso de Francisco Gonzalo -así en 1768, pero convertido en Don en 1790 - a primera vista parece indicar algo distinto. Por las mismas 30 fanegas de tierra en Canto Blanco pagaba, en fecha del primer contrato, 80 reales y el diezmo; en la última escritura se mantenía la mención explícita a los diezmos, pero el alquiler había subido a 300 reales: casi cuatro veces en 22 años. Lo que pasa es que la cantidad inicial era realmente baja, y la subida posterior había servido para adecuar la renta a los precios corrientes. Es un dato difícil de interpretar globalmente, porque son pocos los cánones monetarios, dado que se tendía a estipular los contratos con pago en productos agrícolas. Otro caso, el de una heredad de 136 fanegas en Alcobendas, vio cambiar las condiciones de pago de 40 fanegas de pan por mitad que debía pagar $D^{a}$ María de Auñón en 1762 a 1.224 reales que se le cobraban a $D$. Antonio Méndez por las mismas tierras en 1780. Es decir, se pasaba del cobro en especie a una renta en efectivo, cuando, según todos los resultados de las investigaciones, se empezaba a notar una crisis de producción con la consiguiente subida de los precios de productos agrícolas. Se puede llegar incluso a ver que en varios casos las rentas se reducían en términos de pago en especie, como le ocurrió a Tomás Sanz, sucesor de sus suegros en el arrendamiento de un predio relativamente grande, 136 fanegas y 4 celemines en Vicálvaro; aunque se hacía responsable de las deudas acumuladas por sus parientes, veía cómo se le reducían los cánones de alquiler desde las antiguas 48 fanegas de trigo y otras tantas de cebada a 40 de trigo y 38 de cebada entre 1780 y 1796 . Nos encontramos por tanto ante el hecho, ya notado estadísticamente, de la caída de los arrendamientos en especie que alcanzaron su máximo en los años setenta y ochenta del siglo XVIII-cayendo bruscamente en el siglo siguiente, mientras crecen las rentas en dinero, aunque éstas representan sólo una mínima parte del total de los contratos.

Evidentemente la situación es lo suficientemente compleja como para no admitir ni simplificaciones ni reducciones a modelos preestablecidos. Lo que 
sí es innegable del estudio de las fuenteses que ya en la primera mitad del Setecientos las cláusulas de los documentos revelan una tendencia clara hacia el endurecimiento de las condiciones de pago de los cánones. A escala nacional, en 1765 fue emanada la pragmática sancionando la libertad de estipulación de condiciones en los arrendamientos ${ }^{24}$. En Madrid, los archivos de algunos conventos dan la visión de la realidad económica directa, de lucha entre los derechos de los amos y las necesidades de los campesinos. Tomemos de nuevo en consideración el convento de la monjas bemardas de la Piedad o Vallecas. Los apeos y libros de cuentas coinciden en la sustancial inmovilidad del patrimonio fondiario a partir de 1628 y hasta 1764, período en el que la superficie de los bienes de las monjas pasó de 264 a 270 fanegas de tierra. Pero en el mismo plazo de tiempo se desarrolló una lucha continua entre religiosas y campesinos para evitar las usurpaciones de los segundos. Un primer documento ${ }^{25}$ indica que el convento tenía quince colonos; el segundo es un libro excepcional que brinda la posibilidad de seguir la evolución de las relaciones amos-campesinos durante casi medio siglo, y menciona nueve nombres de colonos de las tierras de las monjas en 1628. La "Declaración de tierras que hicieron los renteros" en 1637 hablaba de 10 arrendatarios para 96 predios y una superficie global de 213 fanegas. Como el apeo más antiguo contenía 264 fanegas, estaba clara la intentona de usurpación de tierras por parte de los colonos que no las declaraban como pertenecientes a las religiosas. Pero la ocultación de $\mathbf{5 0}$ fanegas, es decir el $20 \%$ de los bienes del convento, era demasiado evidente, y dos años después, realizado un nuevo deslinde, afloraban 269 fanegas de patrimonio, apareciendo incluso 27 "olvidadas". Según otro apeo de las mismas monjas para el año de 1699 se nombran ocho colonos, sin indicar las tierras labradas, pero el último registro, más reciente y minucioso, detalla las 270 fanegas de "tierras y heredades de pan coger" de las monjas, y los nombres de los nueve campesinos que las arrendaban.

Por tanto se puede concluir, según parece, que el convento de la Piedad conservaba intacto su patrimonio de tierras agrícolas durante dos siglos, y que el número y movimiento - mínimo-de labradores dependientes probablemente respondía a una necesidad de racionalización del sistema productivo -menos colonos y más tierra para cada uno- que reflejaba también el proceso de estratificación de clases en el mundo campesino. La política de arrendamiento de los fondos rústicos también determinaba la estrategia de adquisición del patrimonio. Los datos se deberán limitar al siglo XVII porque el último libro de registro indica solamente las superficies cultivadas pero no su producto:

\footnotetext{
24 Millä́n y García Varela, op. cit. p.228; Carrera Pujal, op. cit. p. 69.

25 Según la nota 23.
} 
TABLA 8. Rentas agrarias de las monjas bernardas de la Piedad - Vallecas, en fanegas de trigo.

$\begin{array}{llll}1606=130 & 1639=215 & 1660=220 & 1699=203 \\ 1628=151 & 1650=214 & 1668=201 & \end{array}$

Dado que la superficie cultivada no había variado, está claro que los cambios en el producto de las tierras se debían a modificaciones en la labranza o en los sistemas de cobro de las rentas. Desde luego no pueden achacarse a las fluctuaciones de las cosechas pues las fechas están lo bastante alejadas entre sí como para pensar en semejantes coincidencias; pero por otra parte es difícil pensar que si se consiguió casi duplicar la renta entre 16061660 no se siguiera la misma pauta en los períodos siguientes. Parece más razonable hipotizar que los aumentos en el volumen de las rentas se debieran al endurecimiento de las condiciones de arrendamiento, especialmente entre 1628 y 1640 , en que se realizó una inspección global de los bienes arrendados, y que se saldó con un crecimiento del $42 \%$ en los productos obtenidos, es decir de la cuantía de los cánones. También es indicativo que las rentas pagadas por los arrendadores en los últimos treinta años del siglo quedaran prácticamente invariadas.

Es posible que esto ocurriera porque las condiciones contractuales habían alcanzado el máximo nivel exigible a los colonos para asegurar las rentas del convento. Afán que todos los registros de los institutos religiosos reflejan, y testimonian de esta realidad con el sobresaliente cobro de sus rentas en espe$\operatorname{cies}^{26}$ : Roque Gamir Soldado, vecino de Vallecas, hacía el balance de lo que le había supuesto el pago de los arrendamientos en especie por una tierra del monasterio de San Martín. Por una superficie de cuatro fanegas y media, pagaba tres fanegas y medio celemín de pan por mitad

la qual [tierra] asta oy he cstado labrando y disfrutandocomo mía propia, y habiendo reconozido que dicha tierra no tiene Conbeniencia ninguna el labrarla respetto a importar la renta que se paga por ella en cada aîo, más de lo que se coge de ella

decidía devolverla a los monjes ${ }^{27}$. Para las dominicas de Santa Catalina, todos los arrendamientos agrícolas del último cuarto del siglo XVIII se cobraban en numerario y se mantuvieron estables entre 1774 y 1788 , estancados en una ridícula cifra de 642 reales anuales. Como tenían 108 fanegas de tierra, la pro-

26 FERNÁNDEZ DE PINEDO, Coyuntura ... cit, p. 67.

27 En 1731. AHN, 8553, f. 442. 
ductividad media durante esos catorce años fue de unos $60 \mathrm{rs}$,/fanega anuales, bastante menos de lo que podía rendir una casa dada en alquiler en la Corte. En cambio para el monasterio de San Martín los contratos estipulaban el pago de los canones en productos de la tierra en su grandísima mayoría - 33 de 43- en el siglo Dieciocho y la administración se llevaba a cabo con mucho cuidado: según los balances de $\mathbf{1 7 5 4}$ los beneficios de las tierras de labranza eran de 6.688 reales y 425 fanegas de granos; cuantificados en dinero, esas mismas heredades producían en 180863.407 reales, y como las rentas anuales globales del monasterio se mantenían prácticamente al mismo nivel, eso significaba que se había apuntado hacía la actividad más provechosa gracias a la subida de los precios durante toda la segunda mitad de la centuria. Efectivamente, considerando el valor medio de los contratos, se puede observar como a partir de la mitad del siglo crece violentamente, duplicándose en dos ocasiones: 1770 en relación con veinte años antes, y en el último decenio sobre los valores anteriores, así:

TABLA 9. Valor medio de los arrendamientos agrarios del monasterio de San Martín, siglo XVIII, en fanegas de grano/fanega superficie.

\begin{tabular}{cccccccccc}
1710 & 1720 & 1730 & 1740 & 1750 & 1760 & 1770 & 1780 & 1790 & 1800 \\
7 & 13 & 4,3 & 5,6 & 14,2 & 7 & 26,8 & 29 & & 51 \\
\hline
\end{tabular}

\section{La adquisición del patrimonio.}

Aunque muy limitados, los datos manejados indican a las claras la rentabilidad de la propiedad fondiaria - ya urbana, ya agraria — para la obtención de la renta. Por esa razón los religiosos seguían una actitud bien definida con el objeto de asegurarse el dominio sobre el mayor número posible de fincas. Sería interesante poder establecer la estrategia de los conventos para alcanzar dicho fin.

Los datos relativos a los patrimonios de los cenobios madrileños se ciñen a la situación de finales del Setecientos y naturalmente representan el resultado de un proceso doble, temporal por un lado y económico por el otro, de acumulación de bienes de los conventos. Con el curso del tiempo los patrimonios se incrementaron siempre más, ciertamente gracias a los actos de generosidad de los feligreses pero también como consecuencia de la gestión eficaz de los administradores. El punto de partida es el traslado de la Corte a Madrid en 1561 , y de hecho las fechas de fundación de los conventos urbanos se concentran en los años siguientes a ese acontecimiento; en el momento de su funda- 
ción, las casas recibían una sede, más o menos opulenta según las posibilidades de los fundadores, y se les garantizaban algunos ingresos mediante la institución de algunos censos en favor del nuevo convento. Por la tabla 10 se puede comprobar cómo en los sesenta afios transcuridos desde 1570 y 1630 fue fundado el $62,5 \%$ del total de todos los censos cuyas fechas constan para el período 1550-1800. Los decenios en que la práctica de inversión fue más sostenida son los de 1610 y 1620 y luego por orden de importancia los de 1570 y 1580 , en cada uno de los que se escrituró algo más del $10 \%$ del total de los censos de dos siglos. Vistos por períodos de veinticinco años, entre principios del siglo XVIII y 1625 se fechan 285 de 1.020 censos, es decir el $28 \%$ y otro quinto del total entre 1575 y 1600 , así que la mitad de todos los censos se estipularon en tan sólo cincuenta años. Después, a partir de 1650, la cadencia baja mucho y en el siglo XVIII ya es una actividad, como se verá más adelante, que sufre un cierto abandono. Como las dimensiones globales del fenómeno reflejan

TABLA 10. Fecha de escritura de los censos en favor de los conventos madrileños. Número de casos por período.

$\begin{array}{lllllllllll}1550 & 1575 & 1600 & 1625 & 1650 & 1675 & 1700 & 1725 & 1750 & 1775 & 1800\end{array}$

\begin{tabular}{|c|c|c|c|c|c|c|c|c|c|c|c|}
\hline Magdalena & & 4 & 14 & 14 & & & & & & & \\
\hline S. Agustín & & & & 3 & 8 & 13 & 6 & 5 & 3 & 1 & \\
\hline S. Martín & 8 & 38 & 55 & 18 & 3 & 4 & 7 & 31 & 7 & 4 & 6 \\
\hline Vallecas & 6 & 15 & 26 & 67 & 33 & 9 & & & & & \\
\hline Carmen & & & & 24 & 14 & 15 & 11 & 4 & 4 & & \\
\hline Sta. Catalina & & & 40 & 55 & 35 & 29 & 12 & 4 & & & \\
\hline Salutación & 4 & 35 & 71 & 96 & 21 & 2 & 2 & & & & \\
\hline S. Norberto & & & & 8 & 8 & 9 & 3 & & & & \\
\hline Totales & 18 & 92 & 206 & 285 & 122 & 81 & 41 & 44 & 14 & 5 & 6 \\
\hline$\%$ & 1,7 & 9 & 20,1 & 28 & 12 & 8 & 4 & 4,3 & 1,4 & 0,5 & 0,6 \\
\hline
\end{tabular}

fielmente las circunstancias de cada convento tomado singularmente tenemos un dato suficiente para garantizar la exactitud de las conclusiones de conjunto.

Censos yjuros que, encualquier caso, no eran el resultado de los actos fundacionales, sino también el fruto de la diligencia de los administradores de los institutos, y desde este punto de vista la periodización también indica los momentos más elevados de esa actividad y también refleja la práctica corriente de las inversiones, en la que la cumbre más elevada coincide con los momentos de máxima rentabilidad. El siglo XVIII vio el declinar relativo de la actividad

La época de Felipe II y los Austrias

Hispania Sacra 50 (1998) 
crediticia porque para los institutos madrileños era más invitante la gestión de y la inversión en los patrimonios inmobiliarios urbanos a causa de la creciente demanda de viviendas en la Corte.

Es más difícil de efectuar la periodización de obtención del patrimonio de bienes urbanos porque los registros mencionan sólo raramente las fechas de posesión de las fincas o la modalidad de adquisición, por lo que los datos de la tabla 11 darán unas indicaciones de tendencia, que parecen válidas para el conjunto de la realidad estudiada por la naturaleza de las fuentes que los ofrecen. Así, se puede notar que en el curso de más de dos siglos, entre la mitad del Quinientos y el siglo Dieciocho, parece que el despegue en la adquisición de fincas urbanas tuviera lugar en los últimos cincuenta años del Setecientos, con una cantidad tres veces superior a la media de los 150 años anteriores; en cambio los fondos rústicos fueron adquiridos en momentos distintos y siguiendo una dinámica con más altibajos, pues el momento de máxima actividad se sitúa

TABLA 11. Fecha de adquisición de los patrimonios inmobiliarios de los conventos de Madrid. Casos por cada período, fincas urbanas (a) y rústicas, (b).

\begin{tabular}{|c|c|c|c|c|c|c|c|c|c|c|}
\hline & 1550 & 1575 & 1600 & 1625 & 1650 & 1675 & 1700 & 1725 & 1750 & 1775 \\
\hline \multicolumn{11}{|l|}{ (a) } \\
\hline S. Basilio & & & 1 & 7 & 5 & 8 & 3 & 2 & 3 & 1 \\
\hline Portaceli & & & & 2 & & 1 & 3 & 2 & 3 & \\
\hline S. Norberto & & & & 7 & 2 & & 1 & 3 & & \\
\hline \multicolumn{11}{|l|}{ (b) } \\
\hline S. Agustín & & & & 2 & 19 & 24 & 2 & & & \\
\hline S. Felipe R. & & & & & & & 9 & 5 & 16 & 36 \\
\hline Vallecas & & 15 & & 240 & & 8 & 110 & & & \\
\hline Portaceli & & & & & & & & 1 & 7 & \\
\hline Salutación & 10 & 2 & 3 & 2 & & 3 & 4 & 6 & & \\
\hline S. Norberto & & & & 5 & & 1 & & & & \\
\hline
\end{tabular}

entre 1600 y 1625 , con 252 casos; después baja a 57 y de nuevo sube a 137 adquisiciones entre 1700 y 1725 , de tal manera que hay un desfase de un siglo entre el interés por los bienes rústicos y la ola de adquisiciones de fincas urbanas. En comparación con las fechas de imposición de censos y juros, se puede observar un retraso de 25 años puesto que - tabla 10- el máximo de la actividad crediticia se coloca entre 1600 y 1625 . Censos y juros eran las principa- 
les dotaciones de los monasterios madrileños en el momento de su fundación, por lo que parece evidente que primero fueron las rentas necesarias para su funcionamiento y más tarde los institutos se desarrollaron con la adquisición de bienes raíces que consentían no sólo la ampliación física de sus sedes, sino también la obtención de nuevos ingresos ${ }^{28}$.

\section{Las memorias.}

Fundar y dotar una capellanía o memoria en un instituto religioso representaba la manifestación de un sentimiento de fe vivida ${ }^{29}$.Cuantificar la cuantía exacta de las memorias de los conventos es difícil porque a menudo sólo se indicaban sus rentas bajo el título de ingresos por censos, juros $u$ otros bienes con que se sostenían. La fundación de memorias, capellanías u otras obras pías era una práctica originada en la piedad individual, y al pedir a los religiosos una prestación espiritual se les ofrecía una dotación material para sufragarla. Los bienes así obtenidos entraban a engrosar el patrimonio de los cenobios y sus rentas debían teóricamente estar dedicadas a la realización de lo que el fundador dispusiera; pero no siempre era así. El Libro nuevo becerro de administración de los clérigos menores de San Felipe Neri - Portaceli-, es todo un ejemplo del movimiento dado a los bienes fundacionales de las memorias. Las dotaciones económicas se usaban para devolver deudas, comprar casas y fondos rústicos, trabajos de reparaciones en el convento o en sus fincas. Esta contabilidad patentiza también los criterios financieros de la gestión de los spiritualia, pues con la disminución de los tipos de interés, y la consiguiente caída de las rentas de las memorias sostenidas por títulos de crédito, disminuía proporcionalmente también el número de servicios prestados ${ }^{30}$.

28 DOMíngueZ ORTIZ, Aspectos sociales de la vida eclesiástica en los siglos XVIl y XVIII: Historia de la Iglesia en España, IV, Madrid 1979, p. 71: "Carccemos de estadísticas económicas anteriores al Catastro de Enscnada; por cllo sólo podemos conjeturar que los bienes de la Iglesia, que siempre fueron muy grandes, aumentaron en el XVIII más que por donaciones, que ya entonces eran escasas, por las inversiones de aquellas comunidades que tenían exceso de rentas".

29 J. DELuMEAU, El miedo en Occidente, Madrid 1989;ID. Rassurer et protéger, Paris 1989; E. FERNÁNDEZ CUBEIRO, Una práctica de la sociedad rural. Aproximación al estudio de las capellanías en la dióceis compostelana en los siglos XVII y XVIII: La Historia social de Galicia, Santiago 1980.

30 AHN, 7575. Juan de Aguirre

"fundó una memoria de 29 misas rezadas al año a medio ducado cada una [...] dejó de principal un Zenso de $3.230 \mathrm{rs}$. de vellón sobre unas Casas en la calle de la Flor Alta, que haviendola comprado la Exma. $S^{a}$ Duquesa de Altamira redimió la Comunidad dicho Zenso en 24 de Noviembre de 1749; y su Capital le empleó para componer la Bodega de la Villa de Arganda. Y por la rebaja de los Zensos del Cinco al tres, y solo quedan de renta anual 9 ducados, le corresponden 18 missas" (1773, $\mathrm{ff}, 111)$.

La época de Felipe Il y los Austrias

Hispania Sacra 50 (1998) 
TABLA 12. Valores medios de las dotaciones de memorias, en reales de vellón. Siglo XVIII:

\begin{tabular}{lrrrrrrrrrr} 
& 1710 & 20 & 30 & 40 & 50 & 60 & 70 & 80 & 90 & 1800 \\
\cline { 2 - 10 } S. Martín & 911 & 1.398 & 804 & 1.194 & 1.184 & 597 & 1.542 & 5.805 & 5.333 & - \\
S. Basilio & 1.267 & 1.174 & 566 & 460 & 872 & 321 & 726 & 631 & 877 & 148 \\
\hline
\end{tabular}

Son unos valores bastante reducidos, que a un interés del 3\% fructuarían al rededor de treinta reales anuales, en los casos más favorables. Hay que destacar lo elevado - con relación a la media - de los valores de las memorias del monasterio de San Martín para los últimos años del siglo XVIII; pero el hecho de que sólo se trata del dato referido a un contrato en los años ' 80 y a dos en los '90 reduce bastante la posibilidad de explicación estadística.

Los actos de fundación en los registros del monasterio de San Martín oscilan entre modestas donaciones, como la de $\mathrm{D}^{\mathrm{a}}$ Magdalena Iturrañaga, de un censo de 1.700 rs. de capital por ochenta misas rezadas al año, el de $50 \mathrm{rs}$. de renta anual por una misa como pedía $D^{a}$ Andrea de Valdeolmos en 1725, o los 24 reales de Marcos Martínez, con sus modestas pretensiones, hasta el caso de $\mathrm{D}^{\mathrm{a}}$ Luisa de Sosa y Solís, evidente gran benefactora de la casa, quien durante 21 años instituyó con varias dotaciones 1.160 misas rezadas y 16 cantadas al año. En ese período donó al monasterio capitales bajo forma de censos que producían 12.950 rs. de renta anual ${ }^{31}$.También es notable el caso de D. Francisco Franco. En 1742 fundó en el monasterio una memoria consistente en el alquiler de una casa en la calle de San Mateo, de 2.200 rs. anuales; un censo de 25.622 rs. de capital y 768 anuales de renta, otros dos por 66.400 reales en total y que debían producir 1.980 de renta, y una escritura sobre las sisas del camero de Madrid dotada con 24.705 rs. de capital, y renta de 741. En estos

\footnotetext{
Otro caso:

$D^{a}$ Antonia de Mendoza duquesa de Venabente.Fundó memoria de 64 misas rezadas al año, una cada viernes y otra cada mes, pero esta no debe entenderse fundación, por habernos dado la efigie del Sepulcro que se hizo pedazos cuando se caio la Iglesia antigua, y fue preciso recomponerla cuasi en un todo. Lo que sería costoso y se puede reputtar dicha Alaja como perdida sin culpa, por lo que no asignando capital, que fructificase, no es a proposito para capital de memorias de misas perpetuas, y solo será acreedora dicha vien hechora d̀ que se la tenga en especial cuidado para la aplicación de las oraciones y sufragios de la Comunidad" $(1773$, f. 8$)$.

Esto es, la duquesa había hecho un regalo al instituto, bajo forma de obra de arte, entendiénđolo como prenda para que se le rezaran sus misas; pero una vez perdida la donación, por causas accidentales, y dado que no había más capitales para sostener las misas pedidas, éstas no volverían a celebrarse. El carácter contractual de la prestación espiritual queda perfectannente reflejado en este apunte.

31 AHN, 8544. El ejemplo siguiente en 8558, f. 226.
} 
dos últimos casos las fundaciones se realizaban mortis causa y en conjunto los dos piadosos testadores entregaban a los monjes 18.639 reales en rentas fijas anuales, cantidad superior a los ingresos totales de muchas casas de religiosos coetáneas. Estos dos casos sin embargo han sido mencionados por su excepcionalidad. Al menos en el siglo XVIII en los archivos de San Martín no se hallan otros ejemplos de tanta generosidad; los ingresos por memorias eran dados por muchas contribuciones, modestas, bastante parecidas a las rentas de censos y alquileres que los religiosos recibían por otras vías. En algunos casos muy limitados, además, las renuncias a sus bienes que los novicios hacían se interpretaban como fundaciones de memorias o capellanías, puesto que el monje se reservaba la renta de tales bienes hasta su muerte, momento en que pasaban a ser beneficio de la casa ${ }^{32}$. Esto evidentemente no se verificaba cuando los beneficiarios en usufructo eran los padres aún vivos del monje o novicio. Para el monasterio de San Basilio las memorias y donaciones en cada nueva profesión de un monje fueron las vías principales de acceso a la propiedad. Generalmente los novicios nombraban a sus padres o hermanos usufructuarios de sus bienes, y una vez que los derechohabientes habían muerto las propiedades entraban a engrosar el patrimonio de los institutos.

Dificilísimo cuantificarlos, pues los libros sólo hablan de que se hace donación de "todos mis bienes", aunque se desprende que se trata de donaciones modestas, 100 ducados una, 10.186 reales, nada comparable al caso del hijo natural de D. Antonio de Moreda y Garay, caballero de Calatrava, D. Félix, profeso en el monasterio, quien recibió una dote de 44.000 reales primero para él, y a su muerte para la comunidad.Este sistema favorecía la fundación de más memorias y capellanías como renta particular de un religioso encargado de ellas, pero el patrimonio fundacional entraba siempre a englobarse en el del cenobio.

\section{Orígenes de los patrimonios.}

Siempre en los límites de los datos disponibles, el estudio debe preguntarse por los orígenes del patrimonio de los religiosos.El hecho mismo de que la titularidad de juros y censos se desarrollara en el curso de los años indica ya de por sí no todos eran debidos a actos fundacionales, esto es, reducibles a actos de liberalidad de los fieles, sino que lógicamente muchos títulos habían sido adquiridos por los regulares con los activos de sus conventos. De todas las prácticas de aportación de riquezas en favor de un instituto religioso durante la Edad Moderna la más usual consistía en la fundación de memorias. También hay instrumentos de donaciones mortis causa o inter vivos pero son menos

32 Un ejemplo en el archivo de San Basilio, AHN, 6951.

La época de Felipe II y los Austrias

Hispania Sacra 50 (1998) 
frecuentes comparados con las memorias que los feligreses fundaban en un convento, dotándolas con fondos en metálico o títulos de renta --juros o censos- o propiedades inmobiliarias para sufragar los gastos de las condiciones que los fundadores imponían, y que consistían en la celebración de ceremonias por la salud del alma de los fundadores. Antes de aceptarlas, los religiosos a veces realizaban averiguaciones para que

\footnotetext{
se informase si dichas heredades podían ser útiles al Monasterio y con efecto aviendose informado, parece ser útil, y conveniente, admitir dicha cesión con la referida carga [...] pues quedan útiles al Monasterio Ciento Sesenta Reales, y diez y siete marabedís en cada un año.
}

El beneficio económico de la casa se tomaba en consideración también desde otro punto de vista: discutiendo otra vez sobre si valía o no la pena aceptar ciertas tierras como dotación de unas memorias que se quería fundar en el monasterio de San Basilio, los monjes resolvían afirmativamente, porque

administrándolas el Monasterio por sí, respecto tener en el mismo lugar más haciendas con un Monge que las administra es regular produzcan más rentas lo que por al presente ${ }^{33}$.

La memoria no era un mero acto de liberalidad, porque representaba una relación contractual entre el fundador y los religiosos que la aceptaban, en base al cual los eclesiásticos se comprometían a celebrar los oficios religiosos que se les encomendaban y para cubrir los gastos que de ellos se originaran querían asegurarse bien de la rentabilidad de los fondos ofrecidos. De tal manera, si los frailes podían aceptar todos los títulos de renta fija, censos y juros, pasaron por el escrutinio de los administradores sólo las heredades y fincas urbanas que se consideraban productivas y ésas son las que entraban a formar parte del patrimonio inmobiliario del convento.

Establecer la relación entre bienes obtenidos por donación o a título oneroso podría en cierta medida contribuir a graduar el fervor religioso de la sociedad en un momento dado si se acepta que las donaciones en beneficio de los regulares son indicativas de la estima, del respeto o de la confianza que se sentía para con los beneficiarios de semejantes actos. Está claro que la dimensión básica de la fe no les faltó nunca a los madrileños en el curso del Seis y Setecientos, pero sí que cambiaron las manifestaciones de esos sentimientos, y se puede intentar cuantificarlo con varios ejemplos:

33 AHN, 6921, ff. 235r y v, 1751 . 
El caso de San Basilio, monasterio de Premontré fundado en 1608, demuestra que el fervor de fundación de memorias en su momento álgido se concentraba en la mitad de siglo entre 1650 y 1700 , cuando el instituto recibió 47 , es decir más del $51 \%$ de todas las fundaciones. Para los clérigos menores de Portaceli- San Felipe Neri fundado en 1643 el nivel de fundaciones se mantiene constante durante todo un siglo, entre 1650 y 1750 con una media de cuatro por año, con una reducción notable en la segunda mitad del siglo XVIII. Los ricos archivos de San Martín son parcos en datos sobre las memorias fundadas en el monasterio pero los indicadores de las tres casas coinciden en la disminución de nuevas memorias fundadas en los últimos cincuenta años del Setecientos; 10 antes de 1775 en San Basilio, y luego 6 en los diez postreros años de la centuria, trece memorias en Portaceli antes del tercer cuarto del XVIII pero ninguna en los 25 años finales, al igual que en San Martín para el mismo período de tiempo. Son datos parciales pero que probablemente revelan la tendencia de la sociedad, tendencia en la que debía influir la política activa de los Ilustrados. Como dice Domínguez Ortiz:

desde 1640, el descenso en el proceso fundacional es patente, no sólo por el entibiamiento del espíritu religioso, sino porque se había tocado techo ел las posibilidades materiales, y la prolongada crisis humana y económica que atraveś España ponía de relieve la dificultad de mantener con limosnas, dádivas y ofrendas 3.000 conventos cuando ya el campesinado por medio de los diezmos y primicias entregaba una porción muy grande del producto nacional bruto al clero secular ${ }^{34}$.

TABLA 13. Memorias fundadas en algunos conventos de Madrid, 1600-1800. Número de casos.

\begin{tabular}{lcccccccc} 
& 1625 & 1650 & 1675 & 1700 & 1725 & 1750 & 1775 & 1800 \\
\cline { 2 - 7 } & 1 & 3 & 23 & 21 & 4 & 17 & 10 & 6 \\
S. Basilio & & & & & 15 & 10 & 8 & 6 \\
Portaceli & & 1 & 22 & 20 & 21 & 22 & 13 & \\
Total & 1 & 4 & 45 & 41 & 40 & 49 & 31 & 12 \\
\hline
\end{tabular}

Testamentos y compras.

Las sucesiones y donaciones mortis causa representan una aportación im-

34 DOMinguez ORTIZ, Aspectos sociales ... cit, pp. 50-51.

La época de Felipe Il y los Austrias

Hispania Sacra 50 (1998) 
portante a la formación de los patrimonios de regulares aunque menos determinante de lo que a primera vista se pudiera pensar, según la tabla 14:

TABLA 14. Origen de los patrimonios de algunos conventos madrileños, según sus títulos de propiedad, hasta 1800. Porcentajes sobre el total de bienes.

\begin{tabular}{lcccc} 
& $\begin{array}{c}\text { donación } \\
\text { mortis causa }\end{array}$ & memoria & $\begin{array}{c}\text { donación } \\
\text { inter vivos }\end{array}$ & $\begin{array}{c}\text { título } \\
\text { oneroso }\end{array}$ \\
\cline { 2 - 5 } S. Agustín & 76,0 & & & 34,0 \\
S. Felipe Real & 32,5 & & & 67,5 \\
Carmen & 28,6 & 42,8 & 17,3 & 14,3 \\
Portaceli & 10,7 & 21,4 & 7,1 & 58,7 \\
S. Norberto & 34,1 & 9,7 & & 56,1 \\
\hline
\end{tabular}

De entre los ejemplos disponibles, los beneficios de las estipulaciones testamentarias de los feligreses representaban apenas un $10 \%$ del patrimonio del convento de Portaceli, crecida hasta el $76 \%$ de las propiedades de los agustinos de San Agustín, pero teniendo presente que en este caso concreto la relación se ha establecido solamente sobre la superficie de tierras de labranza, 200 fanegas donadas y 63 adquiridas a título oneroso, mientras que el convento también tenía - pero más difícilmente indicables en a tabla - 44 aranzadas de viña recibidas por testamento y otras 31,5 compradas. Esto en lo que se refiere a las superficies, porque el $97,68 \%$ de sus cepas habían sido compradas directamente por los religiosos, lo que demuestra una voluntad de organización y racionalización productiva de su dominio. La ubicación casual de las fincas de los clérigos menores de Portaceli indica también que ese tipo de propiedades no se había originado de una política de compras promovida por el convento, sino que era el fruto de ocasionales donaciones por lo que era imposible elegir o seleccionar su emplazamiento. En cambio, las viñas que compraron en Arganda lo fueron con un objeto muy concreto, en diez años, y hacia el final del siglo XVIII. Los religiosos realizaban de esa manera una diversificación de sus inversiones y apostaban por las tierras precisamente cuando los indicadores de precios tendían a subir. Todo el libro de cuentas es por otra parte un ejemplo evidente del movimiento especulativo que se realizaba con el dinero cobrado por el instituto. Las dotaciones económicas de las memorias se usaban para rescatar censos, comprar casas o fincas rústicas, hacer reparaciones en la fábrica del cenobio ${ }^{35}$.

35 Un ejemplo de la voluntad de organizar y dar coherencia a las propiedades de un convento es el de las franciscanas menores observantes de la Salutación-Constantinopla, en el siglo XVI cuando 
La explotación de ese patrimonio productivo arrancó por tanto de una base debida a la generosidad de los feligreses pero corregida y aumentada por el deseo de mejorar y hacer activa económicamente la propiedad comprando nuevas heredades durante cincuenta años continuados.

La misma especialización queda patente en el caso del convento de San $\mathrm{Fe}$ lipe, para la formación de cuyo patrimonio se compró el $67,5 \%$ de todos los bienes. En realidad el porcentaje debiera ser aun mayor porque sólo se ha podido calcular para las tierras de labor, 27 fanegas de 40 , mientras que el patrimonio incluía otros predios: tres casas, más tierras no especificadas y 67 aranzadas de viña en Illescas, compradas en 113.686 reales, 14 heredades de viñedo y 29 de olivar en Colmenar de Oreja, que habían costado $302.410 \mathrm{rs}, 7$ tierras de labranza y una viña en Pozuelo de Tajo, por los que los monjes pagaran 134.374 reales y una casa en Chinchón en la que se habían invertido 10.000 reales. En total, estos agustinos habían dedicado, entre 1700 y $1798,560.470$ reales a la formación de su patrimonio inmobiliario, mientras habían recibido en el mismo período una donación testamentaria de 13 fanegas de tierra de labranza.

En general es posible afirmar que la mayoría de los bienes raíces de los regulares a finales del siglo XVIII era, un buena parte, fruto de la diligencia de los administradores que habían sabido - y podido - invertir grandes cantidades de dinero en la compra de heredades, más que de los actos de donación de los fieles. El hecho de que estas prácticas hayan sido posibles demuestra claramente que los conventos no eran meras entidades de autoconsumo, ni que se dedicaran a redistribuir sus ingresos bajo forma de caridad, asistencia o gastos suntuarios, sino que también podían disponer de capitales monetarios excedentes de sus gastos de manutención, que usaban con la voluntad de intervención en el mercado y la vida económica. Si luego por razones de su status, o por disponibilidades de capital, o por el volumen de crédito - no sólo económico, sino también social y moral, de que disponían -- su presencia en el mundo de la economía implicaba un cierto grado de distorsión en las relaciones entre factores y actores económicos, entonces se puede explicar fácilmente porqué se convirtieron en el blanco de las críticas y de las tentativas de reforma del Siglo de las Luces.

intentaban, mediante cambios y compras, fundir las heredades esparcidas que habían recibido en đonación en una extensión contigua y más fácilmente explotable y administrable.AHN, 7575.Cfr. BARRIO GOZALO, Los conventos ...cit, p. 639.

La época de Felipe II y los Austrias

Hispania Sacra 50 (1998) 